\title{
Accounting for environmental flow requirements in global water assessments
}

\author{
A. V. Pastor ${ }^{1}$, F. Ludwig ${ }^{1}$, H. Biemans ${ }^{2}$, H. Hoff ${ }^{3,4}$, and P. Kabat ${ }^{1,5}$ \\ ${ }^{1}$ Wageningen University, Earth System Science, Droevendaalsesteeg 3, 6708 PB Wageningen, the Netherlands \\ ${ }^{2}$ Climate Change and Adaptive Land and Water Management Group, Alterra, Wageningen UR, P.O. Box 47, \\ 6700 AA Wageningen, the Netherlands \\ ${ }^{3}$ Potsdam Institute for Climate Impact Research, Telegraphenberg, 14473 Potsdam, Germany \\ ${ }^{4}$ Stockholm Environment Institute, Kräftriket 2b, SE-106 91 Stockholm, Sweden \\ ${ }^{5}$ International Institute for Applied Systems Analysis (IIASA), Schloßplatz 1, 2361 Laxenburg, Austria
}

Correspondence to: A. V. Pastor (amandine.pastor@wur.nl)

Received: 25 October 2013 - Published in Hydrol. Earth Syst. Sci. Discuss.: 10 December 2013

Revised: 30 September 2014 - Accepted: 17 October 2014 - Published: 11 December 2014

\begin{abstract}
As the water requirement for food production and other human needs grows, quantification of environmental flow requirements (EFRs) is necessary to assess the amount of water needed to sustain freshwater ecosystems. EFRs are the result of the quantification of water necessary to sustain the riverine ecosystem, which is calculated from the mean of an environmental flow (EF) method. In this study, five EF methods for calculating EFRs were compared with 11 case studies of locally assessed EFRs. We used three existing methods (Smakhtin, Tennant, and Tessmann) and two newly developed methods (the variable monthly flow method (VMF) and the $Q_{90} Q_{50}$ method). All methods were compared globally and validated at local scales while mimicking the natural flow regime. The VMF and the Tessmann methods use algorithms to classify the flow regime into high, intermediate, and low-flow months and they take into account intra-annual variability by allocating EFRs with a percentage of mean monthly flow (MMF). The $Q_{90} Q_{50}$ method allocates annual flow quantiles $\left(Q_{50}\right.$ and $\left.Q_{90}\right)$ depending on the flow season. The results showed that, on average, $37 \%$ of annual discharge was required to sustain environmental flow requirement. More water is needed for environmental flows during low-flow periods (46-71\% of average low-flows) compared to high-flow periods (17-45\% of average high-flows). Environmental flow requirements estimates from the Tennant, $Q_{90} Q_{50}$, and Smakhtin methods were higher than the locally calculated EFRs for river systems with relatively stable flows and were lower than the
\end{abstract}

locally calculated EFRs for rivers with variable flows. The VMF and Tessmann methods showed the highest correlation with the locally calculated EFRs $\left(R^{2}=0.91\right)$. The main difference between the Tessmann and VMF methods is that the Tessmann method allocates all water to EFRs in low-flow periods while the VMF method allocates $60 \%$ of the flow in low-flow periods. Thus, other water sectors such as irrigation can withdraw up to $40 \%$ of the flow during the low-flow season and freshwater ecosystems can still be kept in reasonable ecological condition. The global applicability of the five methods was tested using the global vegetation and the LundPotsdam-Jena managed land (LPJmL) hydrological model. The calculated global annual EFRs for fair ecological conditions represent between 25 and $46 \%$ of mean annual flow (MAF). Variable flow regimes, such as the Nile, have lower EFRs (ranging from 12 to $48 \%$ of MAF) than stable tropical regimes such as the Amazon (which has EFRs ranging from 30 to $67 \%$ of MAF).

\section{Introduction}

One of the main challenges of the twenty-first century is to manage water and other natural resources so that human needs can be satisfied without harming the environment. By 2050 agricultural production is projected to increase by $70 \%$ compared to 2000, so that enough food can be provided for 9 billion people (Alexandratos and Bruinsma, 2012). This fu- 
ture increase in food production will result in an increase in water demand (Biemans et al., 2011). As a result, about $60 \%$ of the world's population could face surface water shortages from lakes, rivers, and reservoirs Rockström et al. (2009).

Today, $65 \%$ of global rivers are considered as being under moderate-to-high threat in terms of human water security and biodiversity (Vorosmarty et al., 2010). Since the beginning of the twentieth century, more than 800000 dams have been built to facilitate increased withdrawals, and currently $75 \%$ of the main rivers are fragmented (Biemans et al., 2011; Richter et al., 2003). Some large river basins, like the Yellow River basin, have seen their flow reduced by almost $75 \%$ over 30 years due to increasing water withdrawals (Changming and Shifeng, 2002). Moreover, in many rivers, flows are not enough to sustain the deltas. This is the case in, for example, the Colorado and the Nile (Gleick, 2003). In other river basins such as the Amazon or Mekong, flow deviation and dam construction are planned with consequent losses in fish biomass and to the detriment of biodiversity (Ziv et al., 2012).

River flow is the main driver involved in maintaining a river's good ecological status (Poff et al., 2009). Human activities have impaired freshwater ecosystems through excess water withdrawal, river pollution, land use change (including deforestation), and overfishing (Dudgeon, 2000). Stressors associated with reduction in flow and water quality are the most obvious causes of biodiversity hazard as they directly degrade aquatic ecosystems (Vorosmarty et al., 2010; O'Keeffe, 2009; Pettit et al., 2001; Doupé and Pettit, 2002). Between 1970 and 2000 freshwater ecosystem species declined by $36 \%$ (Loh et al., 2010). With increasing future water demand for agriculture, industry, and human consumption, freshwater ecosystems will be under great pressure in the coming decades. Climate change is also expected to affect river discharge and river ecosystems, with decreased low-flows and rising river temperatures predicted (Vliet et al., 2013).

Over the last ten years, global hydrological models (GHMs) have been used to evaluate global water assessments (GWAs) (Arnell, 2004; Alcamo et al., 2007; Rockström et al., 2009; van Beek et al., 2011; Hoff et al., 2010; Hanasaki et al., 2008). Global water assessments have highlighted regions with current and future water scarcity. However, most of these studies have neglected the water required by the environment, also known as environmental flow requirements (EFRs), with only a few studies attempting to include some aspects of environmental flows (Hoekstra and Mekonnen, 2011; Smakhtin et al., 2004; Hanasaki et al., 2008; Gleeson et al., 2012).

According to the Brisbane Declaration (2007), "environmental flows describe the quantity, quality and timing of water flows required to sustain freshwater and estuarine ecosystems and the human livelihoods and well-being that depend on these ecosystems." Environmental flows can also be defined as the flows to be maintained in rivers through manage- ment of the magnitude, frequency, duration, timing, and rate of change of flow events (O'Keeffe, 2009). Environmental flow (EF) methods should take into account the natural variability of river flow by allocating different flow components in order to maintain and/or restore freshwater ecosystems (Acreman et al., 2008) and riparian vegetation (Bunn and Arthington, 2002; O'Keeffe and Quesne, 2009; Kingsford and Auld, 2005; Pettit et al., 2001; Bejarano et al., 2011). For example, sustaining a minimum flow is usually important to guarantee the survival of aquatic species, while flood flows are usually crucial for sediment flushing and for the maintenance of wetlands and floodplains (Hugues and Rood, 2003; Bunn and Arthington, 2002; Acreman et al., 2008; Bigas, 2012). Disrupting a stable flow regime can also impair aquatic ecosystems and favor proliferation of invasive species and more generalist fish species (O'Keeffe, 2009; Marchetti and Moyle, 2001; Poff et al., 2009).

There have been major efforts to define EFRs based on ecohydrological relationships in individual rivers (Richter et al., 2006) but there has been limited upscaling of individual methods to global or regional scales. In general, ecohydrological relationships are far from being linear at local scales. Therefore, defining ecohydrological relationships at the global scale is even more challenging. In a recent study, a world database on fish biodiversity has been developed (Oberdorff et al., 2011) and in other studies, some efforts are shown in relating global ecohydrological responses to flow alteration (Xenopoulos et al., 2005; Iwasaki et al., 2012; Yoshikawa et al., 2013). However, it is still difficult to correlate freshwater biodiversity with flow metrics at both local and global scales (Poff and Zimmerman, 2010).

In current global water assessments, EFRs are almost always neglected or included in a very simplified way. Because EFRs are ignored, the quantity of water available for human consumption globally is probably overestimated (Gerten et al., 2013). To be able to assess where there will be enough water available to allow a sustainable increase in agricultural production, there must be full acknowledgment that nature itself is a water user and limits must be set to water withdrawals in time and space. In the absence of a global ecohydrological assessment, we assume that locally calculated EFRs are the best estimates of the ecological needs of a river and that they can be used for validation of global EF methods.

The aim of this study is to compare different EF methods and their applicability in GHMs to set limits to water withdrawals. In this paper, we first present an overview of existing EF methods. Second, we present the selection and development of five hydrological EF methods that were compared with locally calculated EFRs in 11 case studies. In a final step we present a comparison of the five hydrological EF methods applied to the Lund-Potsdam-Jena managed Land (LPJmL) global hydrological and vegetation model (Bondeau et al., 2007; Gerten et al., 2004). 
Table 1. Description of regional environmental flow methods such as the DRM (Desktop Reserve Model), and New England AquaticBaseFlow (ABF) methods.

\begin{tabular}{llll}
\hline Type of EF method & Data input & Example & Sources \\
\hline Hydrological & $\begin{array}{l}\text { Long-term data sets of } \\
\text { unregulated or naturalized } \\
\text { daily flows ( }>\text { 20 years) }\end{array}$ & $\begin{array}{l}\text { Tennant, Tessmann, } \\
\text { IHA, RVA, DRM, ABF }\end{array}$ & $\begin{array}{l}\text { Babel et al. (2012), Smakhtin et al. (2006), } \\
\text { Tennant (1976), Tessmann (1980), } \\
\text { Richter et al. (1997), Richter (2010), } \\
\text { and Armstrong et al. (1999) }\end{array}$ \\
\hline Hydraulic & $\begin{array}{l}\text { Flow velocity, river } \\
\text { cross-section }\end{array}$ & R2Cross method & Armstrong et al. (1999) \\
\hline Habitat-simulation & $\begin{array}{l}\text { Flow velocity, river cross } \\
\text { section, data set of a fish } \\
\text { specie }\end{array}$ & PHABSIM, IFIM & Capra et al. (2003), Milhous (1999), \\
& $\begin{array}{l}\text { Combination of hydrologi- } \\
\text { cal, hydraulics, ecological, } \\
\text { and social sciences (expert } \\
\text { knowledge) }\end{array}$ & $\begin{array}{l}\text { Building block method } \\
\text { (BBM), ELOHA, } \\
\text { DRIFT }\end{array}$ & $\begin{array}{l}\text { Hughes (2001), King and Louw (1998), } \\
\text { Arthington et al. (2006), Poff et al. (2009), } \\
\text { and Bunn and Arthington (2002) }\end{array}$ \\
\hline Holistic & & \\
\hline
\end{tabular}

\section{Review of environmental flow methods}

\subsection{Locally defined methods}

There are currently more than 200 environmental flow methods (Tharme, 2003). EF methods are classified into four types: hydrological methods; hydraulic rating methods; habitat simulation methods; and holistic methods (Table 1). These EF methods were mainly developed at the river or basin scale, either in the context of flow restoration projects (Richter et al., 2006) or for assessing the ecological status of rivers at a regional, national, or continental level, like the Water Framework Directive 2000/60/EC (Council, 2000).

\subsubsection{Hydrological methods}

Hydrological methods are usually based on annual minimum flow thresholds such as 7Q10, i.e., the lowest flow that occurs for seven consecutive days once in ten years (Telis and District, 1992) or $Q_{90}$, where the flow exceeds $90 \%$ of the period of record (NGPRP, 1974). The first step in determining the desired ecological condition level of a river is often via, for instance, the Tennant method (Tennant, 1976) which defines seven classes ranging from severe degradation $(F)$ to outstanding ecological conditions $(A)$. According to the Tennant classification, a different percentage of the annual flow is allocated during the high-flow and low-flow seasons. The Tessmann method (1980) considers intra-annual variability by allocating percentages of monthly flow to calculate EFRs depending on the different flow seasons (high-, intermediate, or low-flow months). Richter et al. (1997) divided the indicators of hydrological alteration (IHA) into five groups: magnitude, timing, duration, frequency, and rate of change. They determined some environmental flow components (EFCs), such as the maintenance flow, during dry and normal years
(Mathews and Richter, 2007). Alternatively, EFRs can be calculated using a method called the range of variability approach (RVA), which in non-parametric analyses calculates EFRs as a range between the 25th and 75th monthly flow percentile (Armstrong et al., 1999; Babel et al., 2012), or in parametric analyses as a range of mean monthly flow ( \pm standard deviation) (Smakhtin et al., 2006; Richter et al., 2012). The advantage of hydrological methods is that they are simple and fast EF methods for use in preliminary assessments or when ecological data sets are not available. They can easily be implemented at both the local and global scale depending on their level of complexity and the availability of hydrological data.

\subsubsection{Hydraulic methods}

Hydraulic methods are used at a local scale when river crosssection measurements are available. They can ultimately complement habitat simulation models for calculating the area necessary for fish habitat survival (Gippel and Stewardson, 1998; Espegren, 1998). The inconvenience of this method is that it requires river hydraulic measurements and is specific to each river section.

\subsubsection{Habitat simulation methods}

Habitat simulation models make use of ecohydrological relationships. They are based on correlations between hydraulic parameters such as flow velocity and certain species of freshwater ecosystems. For example, the instream flow incremental methodology (IFIM) requires data sets of river discharge, river temperature, and fish species richness (Bovee, 1986; Bovee et al., 1998). The physical habitat simulation model or PHABSIM (Milhous, 1999) is based on the theory that the quality and quantity of physical habitat are related to the en- 
vironmental needs of aquatic ecosystems at each life stage (Palau and Alcázar, 2010; Jowett, 1989). The advantage of habitat simulation models is that they take into consideration riverine ecosystems; however, data collection can be costly and time-consuming. Habitat simulation models also need to be recalibrated when they are applied to a different region and are usually species-specific (McManamay et al., 2013).

\subsubsection{Holistic methods}

Holistic methods are a combination of hydrological, hydraulic, habitat simulation methods, and expert knowledge (Shafroth et al., 2009; Poff et al., 2009). For example, the building block model is a well-documented method for estimating EFRs at either the local or basin scale (King and Louw, 1998; King and Brown, 2010; Tharme, 2003; Hugues and Rood, 2003). The building block method supports the principle that maintaining certain components of the natural flow is of fundamental importance. The flow blocks encompass low-flows and high-flows, both of which are defined for normal and dry years. The Desktop Reserve Model (Hughes, 2001) provides estimates of these building blocks for each month of the year. River streams are classified (from A to D) according to their level of flow alteration, and the decision regarding ecological flows depends on those classes (Kashaigili et al., 2007). The downstream response to imposed flow transformations (DRIFT) is a model that uses 10 ecologically relevant flow categories such as wet and dry seasonal lowflows, periodicity of floods, and flow variability via flow duration curves (Arthington et al., 2003). Finally, the ecological limits of hydrologic alteration (ELOHA) approach includes both a scientific and a social approach. The method uses a hydrological classification of natural flow regime types and calculates the rate of flow alteration between natural and actual conditions. The second part of the method uses ecohydrological relations to determine EFRs, and expert knowledge is included in the final part of the assessment. Holistic methods require time to collect large amounts of data and are difficult to upscale due to the different freshwater ecosystems, flow regime types, water management techniques, and different socio-economic contexts. The strength of holistic methods is that they promote interdisciplinarity where hydrological, geomorphological, biological, and sociological methods are used to find the best compromise between water demand for freshwater ecosystems and water requirements for anthropogenic purposes (Poff et al., 2009).

\subsection{Global environmental flow methods}

Global EF methods are defined using hydrological methods (Sect. 2.1.1) because of the lack of global ecohydrological data (Richter et al., 2006; Poff and Zimmerman, 2010). Smakhtin et al. (2004) developed the first EF method for application within global hydrological models. They defined four potential ecological river statuses: pristine, good, fair, and degraded, following the recommendations of the Department of Water Affairs and Forestry (DWAF, 1997). In their study, a low-flow component is defined for each ecological river status, such as $Q_{50}$ for good ecological status, $Q_{75}$ for moderate ecological status, $Q_{90}$ for fair conditions, and NA for degraded river status. They further developed a method assuming a fair ecological status of global rivers, and $Q_{90}$ was defined as the base flow requirement. To determine high-flow requirements, the global river discharge was classified according to a river's base flow index, which determines the river flow regime. Hanasaki et al. (2008) developed an EF method considering intra-annual variability based on global monthly river flows. They defined four different river regimes: dry, wet, stable, and variable. For each class, they determined EFRs as a percentage of mean monthly flow (MMF) depending on the flow regime type (from 10 to $40 \%$ of MMF). EFRs are also determined with a fair ecological status based on the Tennant method (Hanasaki, personal communication, 2013). Hoekstra and Mekonnen (2012) evaluated monthly EFRs by applying the presumptive environmental flow standard defined by Richter et al. (2012). Although Hoekstra et al. (2012) limited water consumption to $20 \%$ of total discharge, this does not imply that $80 \%$ of the total discharge was unavailable; they showed, however, the period of the year in which net water availability fails to meet water demand. In another recent global water assessment, EFRs were defined as the monthly flow quantile $Q_{90}$ in the PCR-GLOBWB model (Gleeson et al., 2012). In this study, locally calculated EFRs were assumed to be the best estimates of EFRs for validating global hydrological methods. We therefore selected five hydrological EF methods and compared them with 11 locally calculated EFR cases so as to have a simple and reliable global EF method that takes into account intra-annual variability.

\section{Methods}

\subsection{Selection of case studies}

Eleven case studies were selected according to their types of locally defined EF methods, river flow regimes, geolocalizations, and major habitat types (MHTs) (Table 1, Fig. 1). Major habitat types such as temperate coastal rivers and large river deltas are described in the Freshwater Ecoregions of the World (FEOW, Abell et al., 2008), which classify global rivers into 426 freshwater ecoregions. We chose this classification because it is more robust than a simple global river classification, which is usually based on climate zones and/or river discharge (Haines et al., 1988; McMahon et al., 2007). MHT classification is based on riverine species biodiversity, endemism, and river fragmentation. The description of the geo-localization of the case studies is presented in Table 2 and Fig. 1. In our selection of 11 case studies, five sub-groups of MHTs (xeric, temperate, tropical, and po- 


\section{Freshwater Ecoregions of the World (FEOW)}

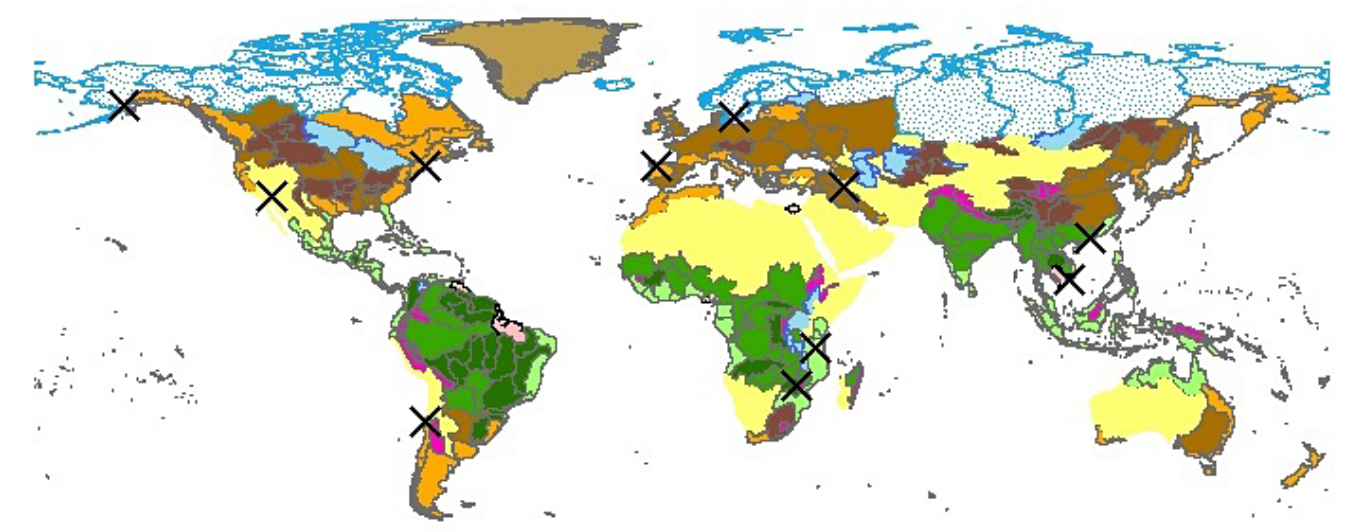

Freshwater Ecoregions of the World (FEOW)

Major Habit at Type

$\square$ enulls

$\square$ large lakes

$\square$ large river deltas

montane freshwaters

oceanic is lands

polar fres hwater

temperate coastal rivers

temperate floodplain rivers and wetlands

temperate upland rivers

tropical and subtropical coastal rivers

topical and subtropical floodplain rivers and wetland complexes

tropical and subtropical upland rivers

xeric freshwaters and endorheic (closed) basins

Figure 1. Locations of the 11 case studies where environmental flow requirements (EFRs) were locally defined.

lar) were represented by at least two case studies. Five out of six continents were represented by at least one or two case studies. The type of flow regimes of the different case studies varied between stable and variable. Finally, the choice of case study was restricted to methods focusing on riverine ecosystems, such as habitat simulation, and/or hydrological methods, based on daily flow data sets.

\subsection{Hydrological data sets}

Hydrological data sets of individual case studies were obtained from the Global Runoff Data Centre (available at http://grdc.bafg.de) or from the authors of the case studies (Table 2). Mean monthly flows were calculated with historical data sets of 8-30 years to represent the "natural" or "pristine" ecological conditions of the river. In other cases, like the Ipswich River case study and the Hong Kong case study, a 20 year average of simulated natural monthly flow was used (Sect. 3.6).

\subsection{Hydrological indices}

The analyses were all computed over a 40 year time period from 1961 to 2000 to take inter-annual variability into ac- 
Table 2. Description of geographic coordinates of the case studies and their hydrological data sets.

\begin{tabular}{|c|c|c|c|c|}
\hline Case studies & Latitude & Longitude & $\begin{array}{l}\text { Daily flow data used } \\
\text { in case studies }\end{array}$ & Daily flow data used in this study \\
\hline $\begin{array}{l}\text { Bill Williams River, USA } \\
\text { (Shafroth et al., 2009) }\end{array}$ & 34.23 & -113.60 & $\begin{array}{l}\text { Pre-dam data } \\
(1940-1965)\end{array}$ & GRDC 4152120 \\
\hline $\begin{array}{l}\text { Ipswich River, USA } \\
\text { (Armstrong et al., 1999) }\end{array}$ & 42.57 & -71.03 & $\begin{array}{l}\text { Ipswich flow data } \\
(1961-1995)\end{array}$ & $\begin{array}{l}20 \text { year LPJmL simulation without } \\
\text { land use and irrigation (PNV run) }\end{array}$ \\
\hline $\begin{array}{l}\text { Silvan River, Spain (Palau } \\
\text { and Alcázar, 2010) }\end{array}$ & 42.37 & -6.63 & $\begin{array}{l}\text { Natural flow data } \\
\text { (1980-1998): } \\
\text { no flow regulation }\end{array}$ & Data set from the authors \\
\hline $\begin{array}{l}\text { Osborne River, Zimbabwe } \\
\text { (Symphorian et al., 2003) }\end{array}$ & -18.75 & 32.25 & $\begin{array}{l}\text { Naturalized flow data } \\
(1961-1973)\end{array}$ & Data set from the authors \\
\hline $\begin{array}{l}\text { Vojm Dam, Sweden } \\
\text { (Renofalt et al., 2010) }\end{array}$ & 62.80 & 17.93 & $\begin{array}{l}\text { Pre-dam data } \\
(1909-1940)\end{array}$ & Data set from the authors \\
\hline $\begin{array}{l}\text { Newhalen River, Alaska } \\
\text { (Estes, 1998) }\end{array}$ & 59.25 & -154.75 & $\begin{array}{l}\text { Pre-dam data } \\
(1951-1986)\end{array}$ & USGS 153000000 \\
\hline $\begin{array}{l}\text { Hong Kong, China (Niu and } \\
\text { Dudgeon, 2011) }\end{array}$ & 22.27 & 113.95 & $\begin{array}{l}\text { Natural flow data } \\
(2007-2008)\end{array}$ & $\begin{array}{l}20 \text { year LPJmL simulation without } \\
\text { land use and irrigation (PNV run) }\end{array}$ \\
\hline $\begin{array}{l}\text { La Nga River, Vietnam } \\
\text { (Babel et al., 2012) }\end{array}$ & 10.82 & 107.15 & $\begin{array}{l}\text { Pre-dam data } \\
(1977-1999)\end{array}$ & Data set from the authors \\
\hline $\begin{array}{l}\text { Great Ruaha River, Tanzania } \\
\text { (Kashaigili et al., 2007) }\end{array}$ & -7.93 & 37.87 & $\begin{array}{l}\text { Pre-dam data } \\
(1958-1973)\end{array}$ & $\begin{array}{l}20 \text { year LPJmL simulation without } \\
\text { land use and irrigation (PNV run) }\end{array}$ \\
\hline $\begin{array}{l}\text { Huasco River, Chile } \\
\text { (UICN, 2012) }\end{array}$ & -28.43 & -71.20 & $\begin{array}{l}\text { Historical data } \\
(1975-1988)\end{array}$ & Data set from the authors \\
\hline $\begin{array}{l}\text { Sharh Chai River, Iran } \\
\text { (Yasi et al., 2012) }\end{array}$ & 37.70 & 45.32 & $\begin{array}{l}\text { Pre-dam data } \\
(1949-2004)\end{array}$ & Data set from the authors \\
\hline
\end{tabular}

count. The flow regimes of the selected case studies were analyzed using several hydrological indicators and river classification. To compare the case studies, we calculated some hydrological flow indices such as the base flow index (BFI) and a hydrological variability index (HVI) as follows in Eqs. (1) and (2):

$$
\begin{aligned}
& \mathrm{BFI}=\frac{Q_{90}}{\mathrm{MAF}} \\
& \mathrm{HVI}=\frac{Q_{25}-Q_{75}}{Q_{50}},
\end{aligned}
$$

where $Q_{90}, Q_{75}, Q_{50}$, and $Q_{25}$ are, respectively, the annual flows equaled or exceeded for $90 \%, 75 \%, 50 \%$ and $25 \%$ of the period of record, and MAF is the mean annual flow. All our calculations are in $\mathrm{m}^{3} \mathrm{~s}^{-1}$. Finally, we classified our case studies by their respective number of low-flow (LF), intermediate-flow (IF) and high-flow (HF) months. LF is defined as MMF less than $40 \%$ of MAF; IF as between equal to or greater than $40 \%$ and less than $80 \%$ MMF of MAF; and $\mathrm{HF}$ as MMF greater than $80 \%$ of MAF (Table 3).

\subsection{Description of the case studies}

The hydrological description of the 11 case studies is shown in Table 3. The first case is the Bill Williams River, located in Arizona, USA, which is classified as the xeric freshwater habitat type and characterized by a long low-flow season (more than 6 months) with a low base flow index $(\mathrm{BFI}=5.3 \%)$. The second case is the Sharh Chai River, which also belongs to the xeric freshwater habitat type. It is characterized by a long period of low-flow (about 6 months) and by a high BFI $(21 \%)$. Four temperate coastal rivers were then selected: the Ipswich River in the USA, the Silvan River in northwest Spain, the upstream flow of the Osborne River in Zimbabwe, and the Huasco River in Chile (Table 3; Fig. 1). These all have relatively stable flow regimes with a strong base flow index $(\mathrm{BFI} \geq 20 \%)$ and a hydrological variability index $(\mathrm{HVI}<1)$. Two case studies were selected in the polar freshwater habitat types: the Vojm River in Sweden and the Newhalen River in Alaska, both rivers are characterized by a strong BFI of 51 and $22 \%$, respectively. Finally, three case studies are located in tropical floodplains and coastal habitat types: a stream near Hong Kong in China, the La Nga River 
Table 3. Hydrological indicator inter-comparison of the case studies. Environmental flow method types are labeled: 1. hydrological, 2. hydraulic, 3. habitat simulation, and 4. holistic. The low-flow average (LF) is calculated as the average flow when MMF > MAF; the high-flow average (HF) is calculated as the average flow when MMF $\leq$ MAF. The base flow index is $Q_{90} /$ MAF (see Eq. 1). The hydrological variability index is $\left(Q_{25}-Q_{75}\right) / Q_{50}$ (see Eq. 2).

\begin{tabular}{|c|c|c|c|c|c|c|c|c|}
\hline Case studies & $\begin{array}{l}\text { Major habitat type } \\
\text { (Abell et al., 2009) }\end{array}$ & $\begin{array}{l}\text { Environmental } \\
\text { flow method type }\end{array}$ & $\begin{array}{l}\text { MAF as } \\
(\mathrm{LF}-\mathrm{HF}) \text { range } \\
\left(\mathrm{m}^{3} \mathrm{~s}^{-1}\right)\end{array}$ & BFI & HVI & $\begin{array}{r}\text { No. } \\
\text { high-flow } \\
\text { months }\end{array}$ & $\begin{array}{r}\text { No. } \\
\text { intermediate } \\
\text { months }\end{array}$ & $\begin{array}{r}\text { No. } \\
\text { low-flow } \\
\text { months }\end{array}$ \\
\hline $\begin{array}{l}\text { Bill Williams River, USA } \\
\text { (Shafroth et al., 2009) }\end{array}$ & Xeric freshwater & 4. HEC-EFM & $\begin{array}{l}2.7 \\
(0.8-5.3)\end{array}$ & 5.3 & 2 & 6 & 0 & 6 \\
\hline $\begin{array}{l}\text { Sharh Chai River, Iran } \\
\text { (Yasi et al., 2012) }\end{array}$ & Xeric freshwater & 1. GEFC (class C) & $\begin{array}{l}5.3 \\
(1.6-12.7)\end{array}$ & 21.1 & 3.3 & 4 & 1 & 7 \\
\hline $\begin{array}{l}\text { Ipswich River, US } \\
\text { (Armstrong et al. 1999) }\end{array}$ & $\begin{array}{l}\text { Temperate coastal } \\
\text { river }\end{array}$ & 2. R2Cross method & $\begin{array}{l}265 \\
(120-556)\end{array}$ & 22.6 & 1.3 & 5 & 2 & 5 \\
\hline $\begin{array}{l}\text { Silvan River, Spain } \\
\text { (Palau and Alcázar, 2010) }\end{array}$ & $\begin{array}{l}\text { Temperate coastal } \\
\text { river }\end{array}$ & $\begin{array}{l}\text { 3. RHYHABSIM } \\
\text { (class B) }\end{array}$ & $\begin{array}{l}0.7 \\
(0.3-0.9)\end{array}$ & 21.5 & 0.9 & 7 & 2 & 3 \\
\hline $\begin{array}{l}\text { Osborne Dam, Zimbabwe } \\
\text { (Symphorian et al., 2003) }\end{array}$ & $\begin{array}{l}\text { Temperate coastal } \\
\text { river }\end{array}$ & $\begin{array}{l}\text { 1. Hugues method } \\
\text { (class B) }\end{array}$ & $\begin{array}{l}39.7 \\
(25.2-55.8)\end{array}$ & 43.6 & 0.6 & 5 & 5 & 2 \\
\hline $\begin{array}{l}\text { Huasco River, Chile } \\
\text { (Pouilly and Aguilera, } \\
\text { 2012) }\end{array}$ & $\begin{array}{l}\text { Temperate coastal } \\
\text { river }\end{array}$ & 3. PHABSIM & $\begin{array}{l}6.2 \\
(5.3-8.9)\end{array}$ & 80.6 & 0.2 & 12 & 0 & 0 \\
\hline $\begin{array}{l}\text { Vojm Dam, Sweden } \\
\text { (Renofalt et al., 2010) }\end{array}$ & Polar freshwater & $\begin{array}{l}\text { 4. Expert } \\
\text { knowledge }\end{array}$ & $\begin{array}{l}39 \\
(16.3-71)\end{array}$ & 51.3 & 0.7 & 6 & 2 & 4 \\
\hline $\begin{array}{l}\text { Newhalen River, Alaska } \\
\text { (Estes, 1998) }\end{array}$ & Polar freshwater & $\begin{array}{l}\text { 1. Tennant } \\
\text { (fair/degrading } \\
\text { class) }\end{array}$ & $\begin{array}{l}284 \\
(98.1-544.3)\end{array}$ & 21.5 & 2.2 & 5 & 2 & 5 \\
\hline $\begin{array}{l}\text { Hong Kong, China (Niu } \\
\text { and Dudgeon, 2011) }\end{array}$ & Tropical floodplain & $\begin{array}{l}\text { 3. Macroinverte- } \\
\text { brates sampling } \\
\text { (degrading and out- } \\
\text { standing classes) }\end{array}$ & $\begin{array}{l}1119 \\
(317-1921)\end{array}$ & 12 & 1.6 & 6 & 2 & 4 \\
\hline $\begin{array}{l}\text { La Nga River, Vietnam } \\
\text { (Babel et al., 2012) }\end{array}$ & $\begin{array}{l}\text { Tropical and subtropi- } \\
\text { cal coastal river }\end{array}$ & $\begin{array}{l}\text { 1. RVA approach } \\
\left(Q_{25}-Q_{75}\right)\end{array}$ & $\begin{array}{l}133.5 \\
(49.4-251.3)\end{array}$ & 15.4 & 1.7 & 5 & 1 & 6 \\
\hline $\begin{array}{l}\text { Great Ruaha River, Tanza- } \\
\text { nia (Kashaigili et al., 2007) }\end{array}$ & $\begin{array}{l}\text { Tropical and subtropi- } \\
\text { cal coastal river }\end{array}$ & $\begin{array}{l}\text { 1. Desktop reserve } \\
\text { model (class } C / D)\end{array}$ & $\begin{array}{l}245 \\
(45-524.4)\end{array}$ & 6.4 & 4.3 & 5 & 1 & 6 \\
\hline
\end{tabular}

in Vietnam, and the Great Ruaha River in Tanzania. These are all characterized by a monsoon season of 3-4 months with a low BFI (between 5 and 15), with the Great Ruaha River characterized by the strongest variability index (4.3). As mentioned in Sect. 2, case studies were selected according to whether EFRs were calculated with EF methods using ecological data sets and/or daily flow data sets. Three case studies used EF methods with ecohydrological relationships such as PHABSIM, RHYHABSIM, and an empirical relationship between macroinvertebrate survival and river flow. One case study (the Swedish case) used a holistic approach by including expert knowledge. One case study used a hydraulic method based on the river cross section in order to assess a suitable area for a fish habitat ( $\mathrm{R} 2$ cross method). In five case studies, hydrological methods were used to determine EFRs at the local scale. Those methods were developed and validated with statistical analyses of daily flow data sets (e.g., GEFC, Hugues method, Tennant, Desktop reserve model).

\subsection{Selection of global environmental flow methods}

In the absence of global ecohydrological relationships, we assumed that locally calculated EFRs were the best estimates for determining EFRs and were thus used for validation of global hydrological EF methods. In this study, we selected three existing hydrological EF methods and developed two new hydrological EF methods that were first compared with the locally calculated EFRs and then implemented in a GHM. The aim was to select and design methods that could be easily implemented in global hydrological models. We excluded EF methods that use daily flows as inputs (e.g., the Hanasaki method) because GHMs are mainly validated on a monthly or annual time scale (Döll et al., 2003; Werth and Güntner, 2010; Portmann et al., 2010; Pokhrel et al., 2011; Biemans et al., 2011). The three selected existing EF methods were the Tennant, Smakhtin, and Tessmann methods. The algorithms of the Smakhtin and Tennant methods were adjusted from using annual to monthly time-steps in order to compare EFRs with monthly irrigation requirements in future water assessments. We therefore divided the river hydrograph into low- and high-flow months and defined an EFRs algorithm 
for each flow season. For example, in the Smakhtin method, low-flow requirements (LFRs) were allocated during lowflow months and high-flow requirements (HFRs) were allocated during high-flow months. By including intra-annual variability in our EF methods, we were able to improve the representation of EFRs compared with EF methods that give an annual flow threshold.

\subsection{Design of new EF methods}

Two of the five EF methods were newly developed for the purpose of this study (Table 4). One method is based on annual flow quantiles (the $Q_{90} Q_{50}$ method) and the other method is based on average monthly flows (the VMF method). We chose to develop a purely non-parametric method ( $\left.Q_{90 \_} Q_{50}\right)$, which uses flow quantiles to allocate minimum instream flow during the high-flow and low-flow seasons. EFRs are calculated using the allocation of the annual flow quantile ( $\left.Q_{90}\right)$ during the low-flow season; the innovation in this method is that the minimum flow threshold was adapted during the high-flow season by allocating the annual flow quantile $\left(Q_{50}\right)$ instead of $\left(Q_{90}\right)$, based on the study of Allain and El-Jabi (2002). Flow quantiles were determined based on long-term average monthly flows between 1961 and 2000. We also developed a parametric method: the variable monthly flow (VMF) method. This method follows the natural variability of river discharge by defining EFRs on a monthly basis as in the Tessmann and Hoekstra methods, except that the VMF method adjusts EFRs according to flow season. The VMF method was developed to increase the protection of freshwater ecosystems during the low-flow season with a reserve of $60 \%$ of the MMF and a minimum flow of $30 \%$ of MMF during the high-flow season. The VMF method allows other water users to withdraw water up to $40 \%$ of the MMF during the low-flow season. In all the EF methods except the VMF method and the Tessmann methods, the low-flow season was determined when the MMF was below mean annual flow (MAF) and the high-flow season when MMF was above MAF. In two of the five methods, intermediate flows were determined for a smooth transition to be made between high-flow and low-flow months (Table 4).

\subsection{Ecological conditions}

At the global scale, there is no data set indicating the level of the ecological condition of rivers; nor is there a data set with the desired ecological status of rivers worldwide. The decision on the ecological status of any river is part of an international consensus between water managers, governments, and environmental scientists. The five hydrological methods were defined with various ecological condition levels. For instance, the Smakhtin method was defined with fair ecological status, while other methods such as the Tessmann method did not define the desired ecological status but allocated at least $40 \%$ of MMF to the river. VMF was defined to reach fair ecological status with a MMF allocation of at least $30 \% \mathrm{MMF}$ and a higher restriction during low-flow months. We excluded methods that used good ecological conditions, such as Hoekstra et al. (2012) because our aim was to validate an EF method based on locally calculated EFRs with fair-to-good ecological conditions. Finally, our focus was to improve the temporal algorithms of EF methods to restrict other water users at monthly time-steps.

\subsection{Validation of EF methods}

The performance of the five hydrological methods was tested against the locally calculated EFRs using the efficiency coefficient $R^{2}$ from Nash and Sutcliffe (1970). In extremely dry conditions $\left(\mathrm{MMF}<1 \mathrm{~m}^{3} \mathrm{~s}^{-1}\right.$ ), there was no environmental flow allocation.

\subsection{Description of the global hydrological model LPJmL and simulations}

The global application and comparison of different EF methods requires the simulation of "pristine" river discharge. For that, the Lund-Potsdam-Jena managed land (LPJmL) model was used to simulate river flow globally at a spatial resolution of $0.5^{\prime}$ by $0.5^{\prime}$ on a daily time step. The CRU TS 2.1 global climate data (1901-2002) was used to drive the model. LPJmL was initially a dynamic global vegetation model simulating water and carbon balances for natural vegetation (Sitch et al., 2003; Gerten et al., 2004). LPJmL is different from other GHMs such as VIC (Liang et al., 1994) and HO8 (Hanasaki et al., 2008) in that it has been extended with a crop model (Bondeau et al., 2007; Fader et al., 2010), with a river routine that simulates water withdrawal from rivers and lakes (Rost et al., 2008), and more recently with the integration of a dam and reservoir module (Biemans et al., 2011).

Simulations were computed from 1901 to 2001 with a spin-up phase of 1000 years for carbon and water balance. A simulation was run for naturalized river flow by using exclusively potential natural vegetation (PNV). EFR calculations were always computed with natural flows obtained from historical data sets or from simulated naturalized flow data sets. All the analyses were done on a monthly time step. In order to compare EF methods globally, the ratio of monthly EFRs to natural monthly flow was used to show the intra-annual variability of EFRs in space and time. Calculations are shown on an annual basis and for two months, January and April, averaged from 1961 to 2000 . We also compared the annual ratio of EFRs for the natural flow of different river basins by giving a range of annual EFRs for the five hydrological methods. 
Table 4. Description of tested hydrological environmental flow methods with MAF (the Mean Annual Flow), MMF (the Mean Monthly Flow), $Q_{90}$ (where the flow exceeded $90 \%$ of the period of record), and $Q_{50}$ (where the flow exceeded $50 \%$ of the period of record). HFRs, IFRs and LFRs are used for high, intermediate, and low-flow requirements, respectively.

\begin{tabular}{|c|c|c|c|c|c|}
\hline Hydrological season & Smakhtin (2004) & Tennant (1976) & $\begin{array}{l}Q_{90 \_} Q_{50} \\
\text { (this study) }\end{array}$ & Tessmann $(1980)^{\mathrm{b}}$ & $\begin{array}{l}\text { Variable monthly flow } \\
\text { (this study) }^{\mathrm{b}}\end{array}$ \\
\hline $\begin{array}{l}\text { Determination of } \\
\text { low-flow months }\end{array}$ & $\mathrm{MMF} \leq \mathrm{MAF}$ & $\mathrm{MMF} \leq \mathrm{MAF}$ & $\mathrm{MMF} \leq \mathrm{MAF}$ & $\mathrm{MMF} \leq 0.4 \cdot \mathrm{MAF}$ & $\mathrm{MMF} \leq 0.4 \cdot \mathrm{MAF}$ \\
\hline $\begin{array}{l}\text { Low-flow requirements } \\
\text { (LFRs) }\end{array}$ & $Q_{90}$ & $0.2 \cdot \mathrm{MAF}$ & $Q_{90}$ & MMF & $0.6 \cdot \mathrm{MMF}$ \\
\hline $\begin{array}{l}\text { Determination of } \\
\text { high-flow months }\end{array}$ & $\mathrm{MMF}>\mathrm{MAF}$ & $\mathrm{MMF}>\mathrm{MAF}$ & $\mathrm{MMF}>\mathrm{MAF}$ & $\begin{array}{l}\mathrm{MMF}>0.4 \cdot \mathrm{MAF} \& \\
0.4 \cdot \mathrm{MMF}>0.4 \cdot \mathrm{MAF}\end{array}$ & $\mathrm{MMF}>0.8 \cdot \mathrm{MAF}$ \\
\hline $\begin{array}{l}\text { High-flow requirements } \\
\text { (HFRs) }\end{array}$ & 0 to $0.2 \cdot \mathrm{MAF}^{\mathrm{a}}$ & $0.4 \cdot \mathrm{MAF}$ & $Q_{50}$ & $0.4 \cdot \mathrm{MMF}$ & $0.3 \cdot \mathrm{MMF}$ \\
\hline $\begin{array}{l}\text { Determination of } \\
\text { intermediate-flow } \\
\text { months }\end{array}$ & - & - & - & $\begin{array}{l}\mathrm{MMF}>0.4 \cdot \mathrm{MAF} \& \\
0.4 \cdot \mathrm{MMF} \leq 0.4 \cdot \mathrm{MAF}\end{array}$ & $\begin{array}{l}\mathrm{MMF}>0.4 \cdot \mathrm{MAF} \& \\
\mathrm{MMF} \leq 0.8 \cdot \mathrm{MAF}\end{array}$ \\
\hline $\begin{array}{l}\text { Intermediate-flow } \\
\text { requirements (IFRs) }\end{array}$ & - & - & - & $0.4 \cdot \mathrm{MAF}$ & $0.45 \cdot \mathrm{MMF}$ \\
\hline
\end{tabular}

\section{Results}

\subsection{Comparison of global environmental flow requirements per case study}

The overall annual average of EFRs across the 11 case studies and five methods represent $37 \%$ of MAF (Fig. 2; Table 5). The range of EFRs defined locally in the case studies is from 18 to $63 \%$ of MAF, while the range of EFRs among the global EF methods is from 9 to $83 \%$ of MAF. On average, low-flow requirements represent $46-71 \%$ of mean low-flows, while high-flow requirements represent $17-45 \%$ of high-flows (Table 5). Low-flow requirements are usually higher than high-flow requirements relative to MAF when the low-flow season is longer than four months. The correlation between the EFRs calculated with the five selected methods and the locally calculated EFRs are shown in Fig. 3. Among the EF methods used, all the simulated EFRs were highly correlated with the locally calculated EFRs. The Tessmann and VMF methods recorded the highest correlation coefficient $\left(R^{2}=0.91\right)$, while the Smakhtin, $Q_{90} Q_{50}$, and Tennant methods showed a correlation $\left(R^{2}\right)$ of $0.86-0.88$.

The results show that while there is no unique method fitting a unique habitat type, two of the five methods (VMF and Tessmann) performed better than the three other methods (Smakhtin, $Q_{90} Q_{50}$, and Tennant). On average, the Tennant method allocated about $10 \%$ less water than the locally calculated EFRs. The Tessmann method was in general higher than the locally calculated EFRs $(+24 \%)$, especially in polar freshwater ecosystems. The Smakhtin and $Q_{90 \_} Q_{50}$ methods allocated less water than recommended in xeric freshwater and tropical freshwater ecosystems (variable flow regimes) and allocated more water than recommended in polar freshwater ecosystems (stable flow regime). Finally, the VMF method was the closest to the locally calculated EFRs (about $10 \%$ above average). The five methods gave lower EFRs estimates than the locally calculated EFRs in xeric freshwater ecosystems and higher estimates of EFRs than locally calculated EFRs in polar freshwater ecosystems. The methods that were closer to the locally calculated EFRs for xeric freshwater ecosystems were Tessmann and the VMF methods, and for polar freshwater ecosystems, the Tennant method. For temperate coastal rivers, the method closest to the locally calculated flow was the VMF method (Fig. 2; Table 5).

EFRs of variable rivers accounted for more than $60 \%$ of the total annual flow during the high-flow season. For example, in the case of the Bill Williams River and the Iranian case studies, about $80 \%$ of the river flow occurs during the highflow season which lasts three to five months. In the Tanzanian case, the high-flow season lasts five months during which $90 \%$ of the total flow occurs and about $80 \%$ of EFRs are allocated. The Tessmann, VMF, and $Q_{90} Q_{50}$ methods were in line with the locally calculated EFRs of variable rivers, but only the VMF and Tessmann methods could capture the intra-annual variability and allocated peak flows during the high-flow season (Fig. 2; Table 5).

In perennial rivers, such as the Chilean case study, about $40 \%$ of the total flow occurs during the three wettest months of the year with the allocation of more than $50 \%$ of EFRs. The Tessmann, Tennant, and VMF methods were in line with the locally calculated EFRs, while the Smakhtin and the $Q_{90} Q_{50}$ methods allocated more water than recom- 

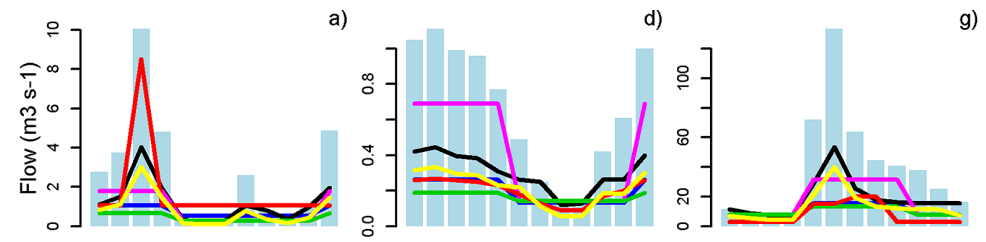

g)
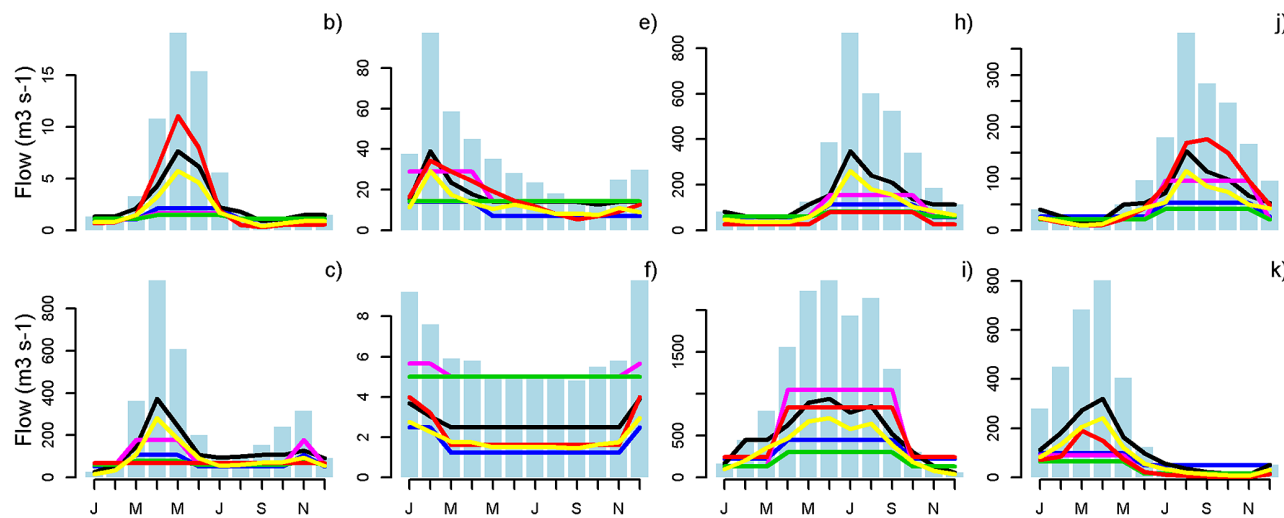

Figure 2. Comparison of EF methods with locally calculated EFRs in different case studies (a) Bill Williams River, USA, (b) Sharh Chai River, Iran (c) Ipswich River, US, (d) Silvan River, Spain, (e) Osborne Dam, Zimbabwe (f) Huasco River, Chile (g) Vojm Dam, Sweden, (h) Newhalen River, Alaska, (i) Hong Kong stream, China, (j) La Nga River, Vietnam, and (k) Great Ruaha River, Tanzania. Observed or simulated natural flows from the case studies are presented in light blue, except for the natural flows (c) and (e) which were simulated with LPJmL.

Table 5. Comparison of annual average environmental flow requirements (EFRs) by method and case study. EFR: environmental flow requirements; LFR: low-flow requirements; and HFR: high-flow Requirements. EFR is expressed as a percentage of mean annual discharge of river in "natural" conditions; LFR is expressed as a percentage of mean annual low-flow; HFR is expressed as a percentage of mean annual high-flow.

\begin{tabular}{|c|c|c|c|c|c|c|c|c|}
\hline Case studies & $\begin{array}{l}\text { MHT class } \\
\text { (Abell et al., } \\
2009 \text { ) }\end{array}$ & $\begin{array}{l}\text { EFR case } \\
\text { study (LFR- } \\
\text { HFR) }\end{array}$ & $\begin{array}{l}\text { Variable } \\
\text { monthly flow } \\
\text { (LFR-HFR) }\end{array}$ & $\begin{array}{l}\text { Smakhtin } \\
\text { (LFR-HFR) }\end{array}$ & $\begin{array}{l}\text { Tennant } \\
\text { (LFR-HFR) }\end{array}$ & $\begin{array}{l}\text { Tessmann } \\
\text { (LFR-HFR) }\end{array}$ & $\begin{array}{l}Q_{90-} Q_{50} \\
\text { (LFR-HFR) }\end{array}$ & $\begin{array}{l}\text { Average all } \\
\text { EFR results } \\
\text { (average LFR- } \\
\text { average HFR) }\end{array}$ \\
\hline $\begin{array}{l}\text { Bill Williams River, USA } \\
\text { (Shafroth et al. 2009) }\end{array}$ & Xeric freshwater & $63(133-48)$ & $33(46-30)$ & $12(18-11)$ & $27(67-18)$ & $46(72-40)$ & $6(18-3)$ & $46(48-26)$ \\
\hline $\begin{array}{l}\text { Sharh Chai River, Iran } \\
\text { (Yasi et al., 2012) }\end{array}$ & Xeric freshwater & $51(42-53)$ & $35(56-30)$ & $19(70-15)$ & $27(66-17)$ & $50(90-40)$ & $19(70-13)$ & $33(66-28)$ \\
\hline $\begin{array}{l}\text { Ipswich River, USA } \\
\text { (Armstrong et al., 1999) }\end{array}$ & $\begin{array}{l}\text { Temperate coastal } \\
\text { river }\end{array}$ & $25(56-12)$ & $35(47-30)$ & $25(50-14)$ & $27(44-19)$ & $49(60-30)$ & $37(44-19)$ & $33(46-17)$ \\
\hline $\begin{array}{l}\text { Silvan River, Spain (Palau and } \\
\text { Alcázar, 2010) }\end{array}$ & $\begin{array}{l}\text { Temperate coastal } \\
\text { river }\end{array}$ & $34(58-28)$ & $34(50-30)$ & $26(54-20)$ & $33(56-28)$ & $46(73-40)$ & 77 (89-74) & $43(63-37)$ \\
\hline $\begin{array}{l}\text { Osborne Dam, Zimbabwe } \\
\text { (Symphorian et al., 2003) }\end{array}$ & $\begin{array}{l}\text { Temperate coastal } \\
\text { river }\end{array}$ & $46(84-13)$ & $32(44-27)$ & $44(73-26)$ & $27(34-24)$ & $46(66-35)$ & $59(73-53)$ & $44(62-29)$ \\
\hline $\begin{array}{l}\text { Huasco River, Chile (Pouilly } \\
\text { and Aguilera, 2012) }\end{array}$ & $\begin{array}{l}\text { Temperate coastal } \\
\text { river }\end{array}$ & $34(30-42)$ & $30(30-30)$ & $81(94-56)$ & $25(23-28)$ & $44(47-44)$ & $83(94-64)$ & $54(53-45)$ \\
\hline $\begin{array}{l}\text { Vojm Dam, Sweden } \\
\text { (Renofalt et al., 2010) }\end{array}$ & Polar freshwater & $20(18-21)$ & $34(45-30)$ & $51(123-28)$ & $28(48-22)$ & $48(72-40)$ & $69(123-52)$ & $43(71-32)$ \\
\hline $\begin{array}{l}\text { Newhalen River, Alaska } \\
\text { (Estes, 1998) }\end{array}$ & Polar freshwater & $18(27-14)$ & $35(53-30)$ & $20(62-15)$ & $32(58-21)$ & $30(88-40)$ & $50(63-29)$ & $30(59-25)$ \\
\hline $\begin{array}{l}\text { Hong Kong, China } \\
\text { (Niu and Dudgeon, 2011) }\end{array}$ & Tropical floodplain & $48(77-44)$ & $53(50-30)$ & $19(42-16)$ & $30(71-23)$ & $40(82-40)$ & $53(42-54)$ & $38(67-32)$ \\
\hline $\begin{array}{l}\text { La Nga River, Vietnam } \\
\text { (Babel et al., 2012) }\end{array}$ & $\begin{array}{l}\text { Tropical and subtropi- } \\
\text { cal coastal river }\end{array}$ & $53(50-54)$ & $35(52-30)$ & $28(31-9)$ & $28(54-21)$ & $48(75-40)$ & $38(42-38)$ & $39(51-32)$ \\
\hline $\begin{array}{l}\text { Great Ruaha River, Tanzania } \\
\text { (Kashaigili et al., 2007) }\end{array}$ & $\begin{array}{l}\text { Tropical and subtropi- } \\
\text { cal coastal river }\end{array}$ & $22(19-22)$ & $33(54-30)$ & $15(35-12)$ & $28(109-19)$ & $46(92-40)$ & $19(58-17)$ & $25(61-19)$ \\
\hline Average per method & & $37(43-28)$ & $40(48-30)$ & $31(59-20)$ & $32(57-22)$ & $40(74-39)$ & $43(65-38)$ & $37(56-34)$ \\
\hline
\end{tabular}



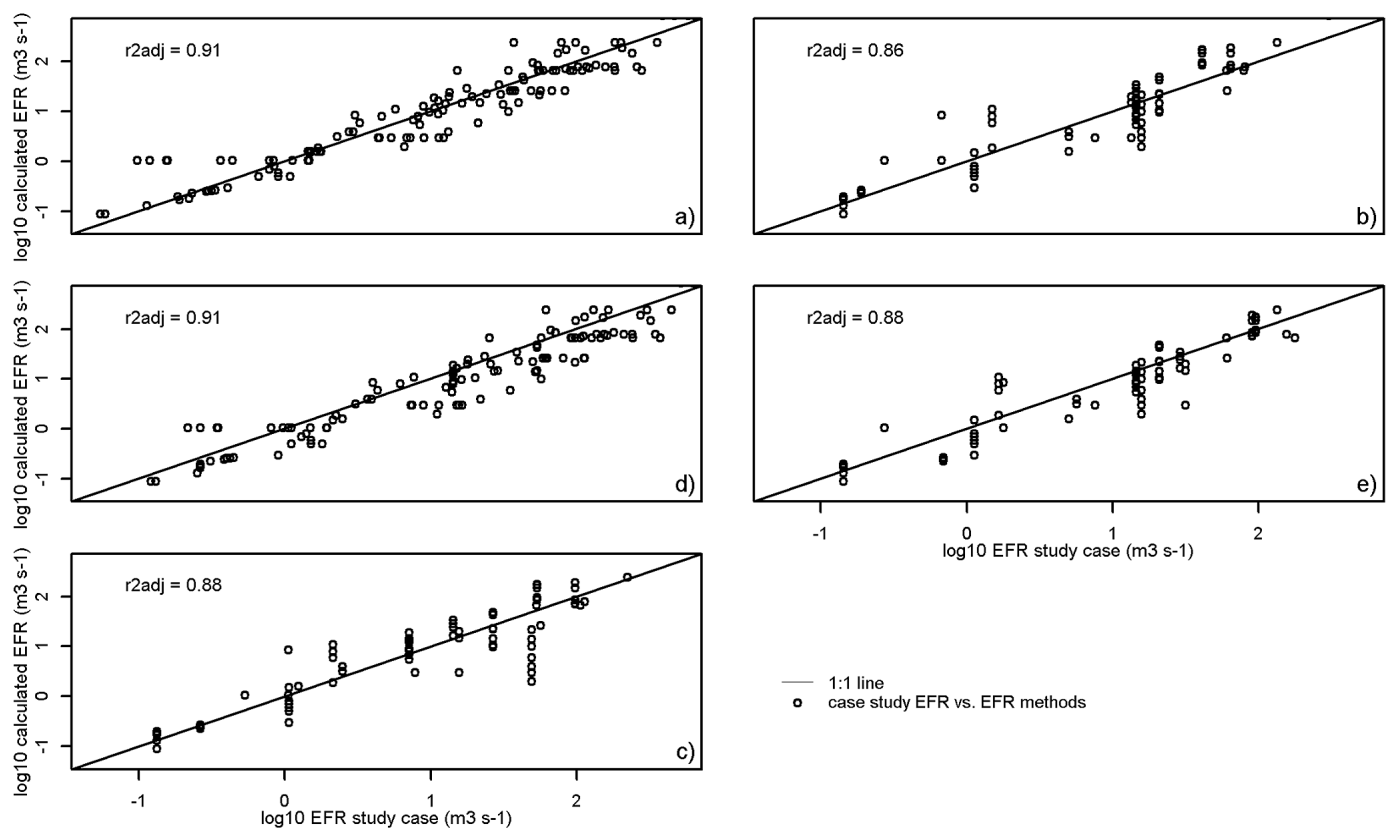

- $1: 1$ line
case study EFR vs. EFR methods

Figure 3. Relation between the monthly calculated EFRs and the locally calculated monthly EFRs of 11 case studies with the (a) variable monthly flow, (b) Smakhtin, (c) Tessmann, (d) $Q_{90} Q_{50}$, and (e) Tennant methods. In each subfigure, each dot represents EFRs for one month and for one case study.

mended. In the Odzi River in Zimbabwe, only Tessmann and $Q_{90} Q_{50}$ could allocate an amount of water close to the locally calculated EFRs. In the Vojm River in Sweden, all the EF methods used were in line with the locally calculated EFRs with the exception of the timing of the peak flow, which was calculated as being two months later with the locally calculated EFRs.

\subsection{Comparison of environmental flow methods globally}

Among the methods, EFRs ranged from $25-46 \%$ of MAF, with an increasing percentage of EFRs from the Smakhtin method to the $Q_{90} Q_{50}$ method. On a monthly basis, the VMF, Tennant, and Tessmann methods produced a similar spatial distribution of EFRs. Similarly, the Smakhtin and $Q_{90} Q_{50}$ methods showed analogous spatial allocation of EFRs such as a high water allocation in perennial rivers, and a low to no-flow allocation in variable rivers. The Smakhtin method allocated $100 \%$ of MMF in the regions of the Arctic North Pole, between 40 and $60 \%$ of MMF in the tropics, and between 0 and $40 \%$ of the MMF in the rest of the world. The VMF, Tennant, and Tessmann methods allocated from at least 20 to $40 \%$ of MMF in arid regions and more than $50 \%$ of the MMF during the low-flow season. The Tennant method calculated high EFRs in the tropics (EFRs $\geq 100 \%$ of MMF). However, the Tennant method calculated lower EFRs than the rest of the methods in temperate zones, especially during the high-flow period. In the temperate zones, the Tennant method allocated about $20 \%$ of MMF, while the VMF and Tessmann methods allocated at least $40 \%$ of MMF. A comparison of Fig. 4 with Figs. 5 and 6, shows that EFRs are more homogenous on an annual time-step compared to a monthly time-step because monthly EFRs are averaged out. For example, the Tessmann method allocated an equal percentage of MAF worldwide and did not show strong differences between regions (Fig. 4), whereas, on a monthly basis, the Tessmann method showed clear spatial differences in flow allocation (Figs. 5 and 6).

Using a combination of the five EF methods can give a range of uncertainties of EFRs in the absence of any locally calculated EFRs. For example, we present a range of EFRs calculated with the five hydrological EF methods at the outlet of 14 of the world's biggest river basins. The results show that perennial rivers such as the Congo, Amazon, Rhine, and Mississippi required $30-80 \%$ of MAF (Fig. 7). More variable river basins such as the Ganges or the Nile required 10 $50 \%$ of MAF depending on the five EF methods. On average, $Q_{90} Q_{50}$ resulted in the highest EFRs (48\% of MAF) and the Smakhtin method resulted in the lowest EFRs (26\% of MAF). The VMF method allocated on average $33 \%$ of MAF, which is higher than the Tennant method ( $30 \%$ of MAF) and lower than the Tessmann method ( $43 \%$ of MAF). 

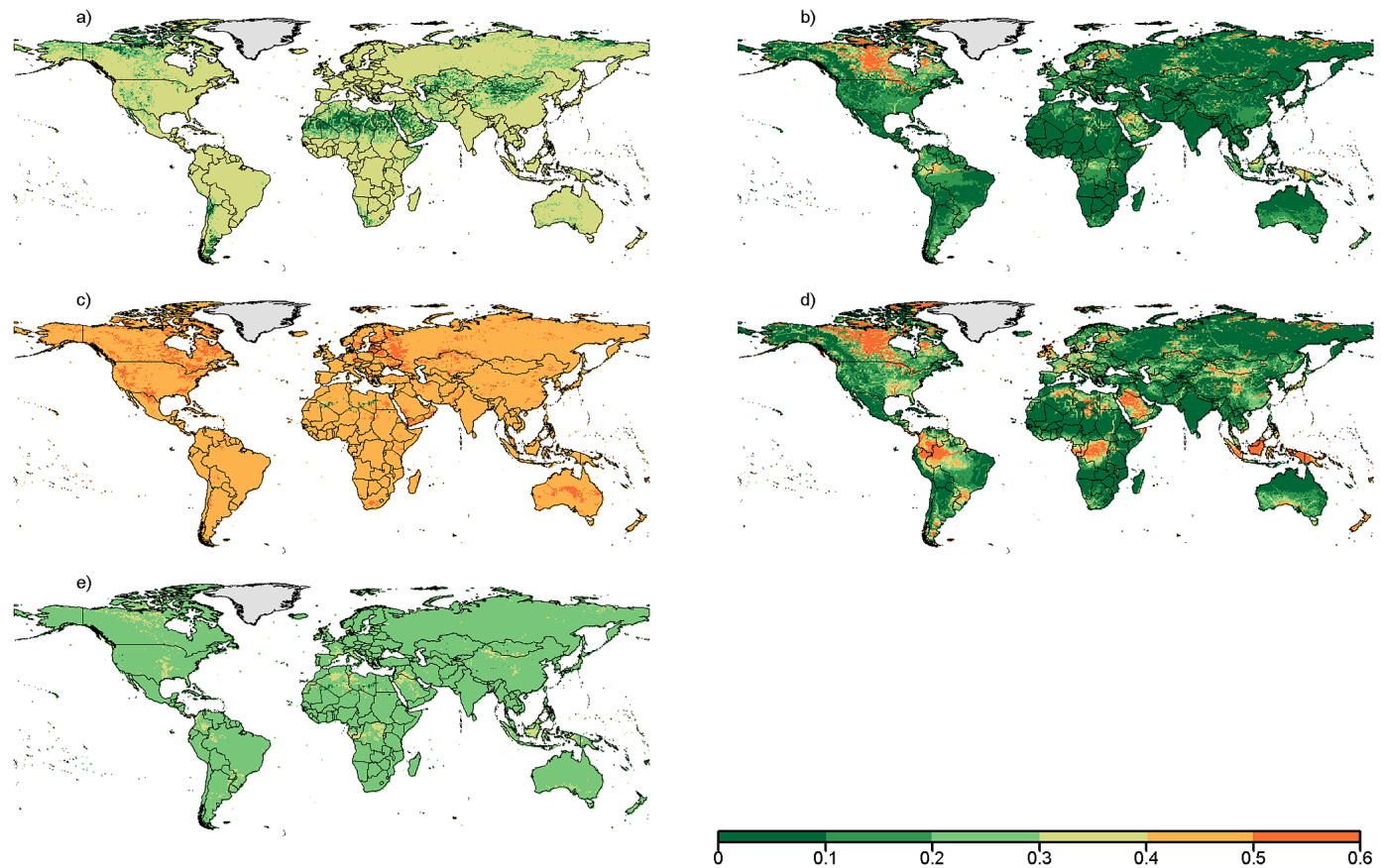

Figure 4. Ratios of annual environmental flow to annual natural flow calculated using the (a) variable monthly flow, (b) Smakhtin, (c) Tessmann, (d) $Q_{90} Q_{50}$, and (e) Tennant environmental flow methods.
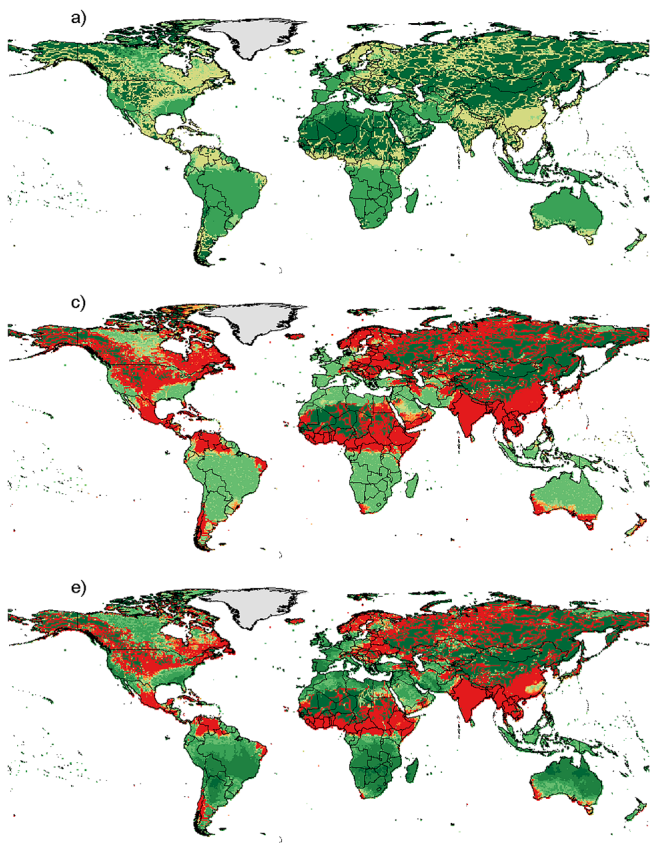
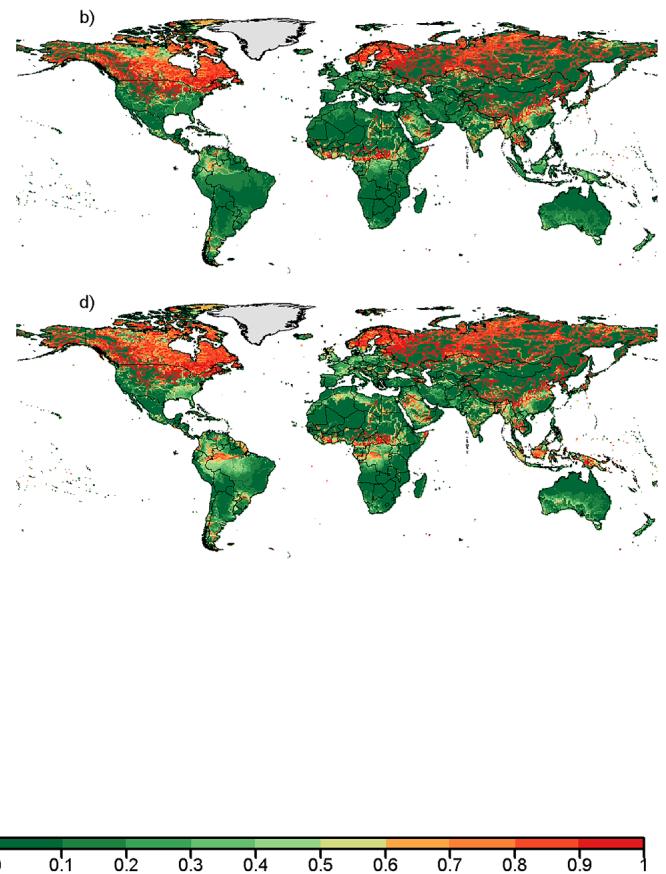

Figure 5. Ratios of monthly environmental flow to monthly actual flow (January) for the (a) variable monthly flow, (b) Smakhtin, (c) Tessmann, (d) $Q_{90} Q_{50}$, and (e) Tennant environmental flow methods. 

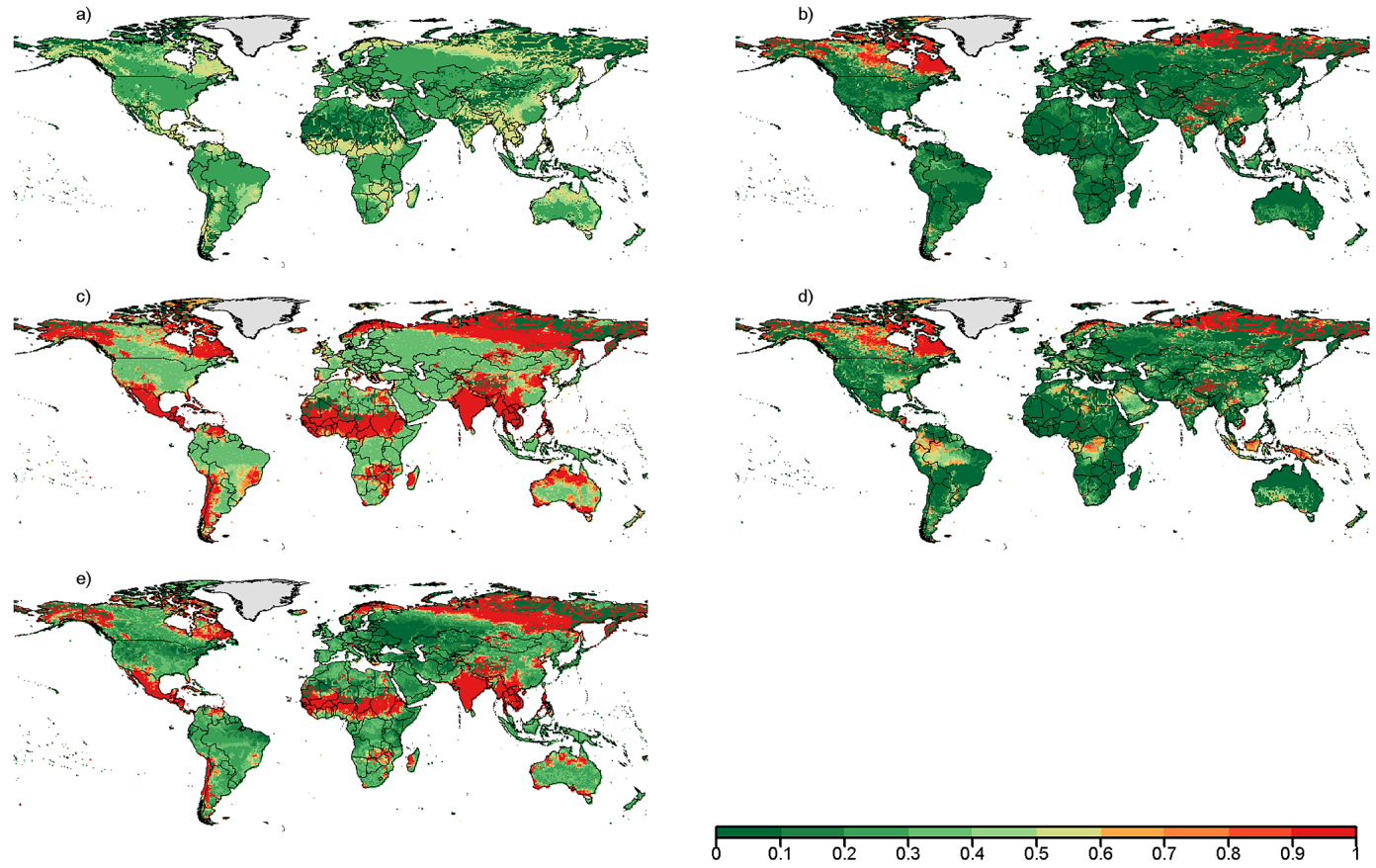

Figure 6. Ratios of monthly environmental flow to monthly actual flow (April) for the (a) variable monthly flow, (b) Smakhtin, (c) Tessmann, (d) $Q_{90} Q_{50}$, and (e) Tennant environmental flow methods.

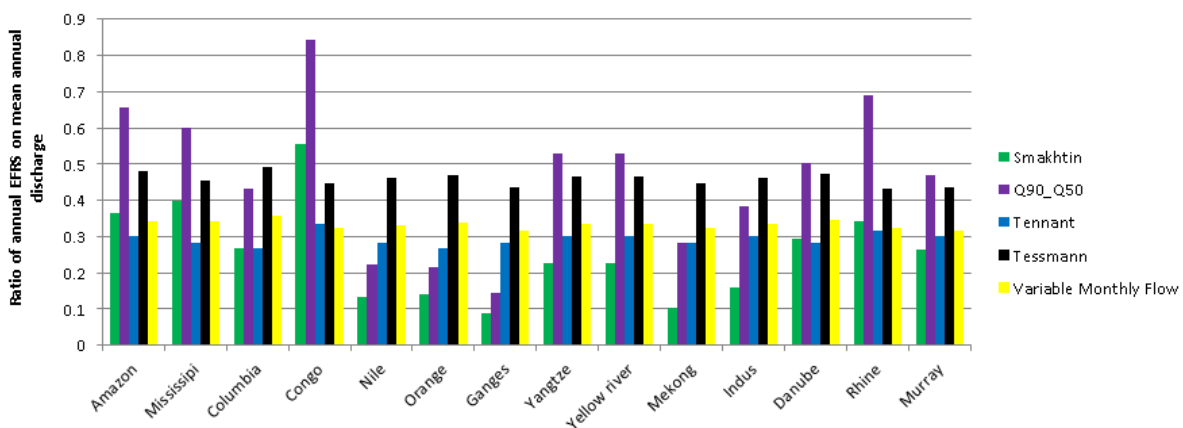

Figure 7. Comparison of the five environmental flow methods at the outlets of 14 river basins.

\section{Discussion}

\subsection{Improving global environmental flow assessments}

This study compared a selection of hydrological EF methods with locally calculated EFRs while accounting for intraannual variability. Five hydrological methods were tested using a set of local case studies to identify methods that could be used in future global water assessments. The inclusion of intra-annual variability in the algorithm of EF methods presents a significant improvement over previous global water assessments based on an annual scale (Smakhtin et al., 2004; Vorosmarty et al., 2010). The VMF method was developed with the specific aim of being flexible, reliable, and globally applicable. The VMF and Tessmann methods showed a good correlation with the locally calculated EFRs in different case studies from a wide range of climates, flow regimes, and freshwater ecosystems $\left(R^{2}=0.91\right)$. Both methods classify flow regime into high, intermediate, and lowflow seasons and allocate monthly EFRs with different percentages of the MMF or MAF. Those two methods show some temporal and spatial improvements in the calculation of EFRs, especially for the variable flow regimes, compared with methods using annual flow thresholds such as low-flow indices $\left(Q_{90}\right.$ or $\left.7 Q_{10}\right)$ or percentages of MAF (Palau, 2006). The advantage of the VMF and the Tessmann methods is that they mimic the natural flow as suggested by Poff et al. (2009). In the case of the VMF method, the allocation of $30-60 \%$ of mean monthly flow as a degradation limit was selected because the purpose of this study was to allocate water for freshwater ecosystems in fair ecological conditions similar to Smakhtin et al. (2004), and an allocation of $30 \%$ of 
MAF to calculated EFRs was widely recognized (Hanasaki et al., 2008).

\subsection{Differentiation between Tessmann and VMF methods}

The main difference between the VMF and Tessmann methods is that they define high-flow, intermediate-flow, and lowflow seasons with different algorithms (Table 4). They allocate 60 and $100 \%$, respectively, of MMF during the low-flow season. The relative amount of EFRs during the low-flow period is high because we considered the habitat area for freshwater ecosystems to be smaller during the low-flow season compared to the high-flow season, and we also wished to prevent the eventual impact of seasonal droughts on freshwater ecosystems (Bond et al., 2008). Saving water for the environment is thus more important during the low-flow season in order to reduce the pressure on fish survival. This assumption was confirmed in the study of Palau and Alcázar (2010), and our calculated LFRs were close to the requirements of fish habitat survival. On the other hand, water users such as industry and the irrigation sector can still withdraw up to $40 \%$ of MMF during the low-flow season (which is usually the season with the highest water demand from the irrigation sector). However, with the Tessmann method, water withdrawals are not possible during the low-flow season. During the highflow season, allocation of HFRs does not differ significantly between the VMF and Tessmann methods because the VMF method allocates $30 \%$ of MMF and the Tessmann method allocates $40 \%$ of MMF. The determined threshold levels of the VMF method can easily be adjusted depending on the objectives of the water policy (e.g., a stricter policy on riverine ecosystems may require higher EFRs thresholds), on the ecological status of a river basin (a very altered river may never achieve the actual thresholds of VMF), and on the specific demands of other water users.

\subsection{Limitations of environmental flow methods based on annual thresholds}

We found that EFRs calculated with methods based on annual thresholds (Tennant, Smakhtin, and $Q_{90} Q_{50}$ ) were lower during low-flow season and higher during high-flow season than the locally calculated EFRs, even if intra-annual adjustment was included (allocation of low- and high-flow requirements). Using annual flow quantiles to calculate EFRs is not appropriate for certain types of flow regime. For example, using the $Q_{90} Q_{50}$ or the Smakhtin method, the calculated EFRs were always lower than the locally defined EFRs of variable rivers (Fig. 2). The Tennant method did not perform well in tropical case studies because this method was developed for temperate rivers and thus needs to be calibrated for other river types. The flow quantile methods, such as the Smakhtin and $Q_{90} Q_{50}$ methods, showed that in perennial rivers, as in the Chilean case, there was a higher allo- cation of EFRs compared to other methods (Figs. 1, 3, 4, and 5). In variable rivers, the $Q_{90} Q_{50}$, the Smakhtin and Tennant methods showed a lower allocation of EFRs during the high-flow season and a higher allocation of EFRs during the low-flow season compared to the locally calculated EFRs (Table 5). Similarly, those methods did not seem appropriate for ephemeral and intermittent rivers because they would be flooded during the dry season, which can increase the risk of exotic species invasion (O'Keeffe, 2009). Furthermore, Botter et al. (2013) agreed with the fact that allocating fixed minimum flows to erratic flow regimes was not appropriate; this is because those flow regimes have a high-flow variability and allocating a fixed minimum flow would be disproportionate to the incoming flows during the low-flow season. Furthermore, flow quantile methods are not flexible enough to be used in global assessments because the allocation of higher flow quantiles than $Q_{90}$ such as $Q_{75}$ and $Q_{50}$, as suggested in Smakhtin et al. (2004), would allocate a flow exceeding the average monthly flow (data not shown).

\subsection{Limitations of our study}

The choice of EF methods for our study was limited to hydrological methods because of a lack of data on ecosystem responses to flow alterations for most river basins of the world. This lack of ecohydrological data makes it difficult to determine minimum environmental flow thresholds and tipping points of different freshwater ecosystem across the world. An improved consistent ecohydrological monitoring and forecasting system is required so that a global river classification system can be developed that would account for the sensitivity of the respective aquatic ecosystems to flow modifications (Barnosky et al., 2012). To go beyond previous individual unrelated case studies we consistently applied different EF methods across a set of existing case studies located in different climates and freshwater ecosystems regions. Among the 200 existing EF methods, it is difficult to find case studies that quantify the sensitivity of freshwater ecosystems to change in discharge (Poff and Zimmerman, 2010). It would be a great improvement if the number of case studies could be increased so that the level of validation could be increased and more accurate algorithms for each ecoregion could be found. For example, a higher allocation of flow might be required in perennial tropical rivers due to their high biodiversity index (Oberdorff et al., 2011) and due to their lower hydrological resilience to climate fluctuation compared to rivers with more variable flow regimes (Botter et al., 2013). We are aware of the heterogeneity of the case studies in terms of inter-annual variability and for that reason we chose case studies with a minimum of 15 years of hydrological data, which is sufficient to capture inter-annual variability, according to Kennard et al. (2010). However, none of the EF methods used in this study explicitly accounted for daily high and low flood pulses, which often drive riparian vegetation (Shafroth et al., 2009). 


\subsection{Social aspects of environmental flow requirements}

Environmental flow requirements are, ultimately, a societal decision which is often made at local scales, and quantification of EFRs depends on the level of protection that is desired by society/policy. However, to develop a global EF method we need a quantification method that can be used in global water hydrological models. We decided to develop a method that reflects a level of ecosystem described as being in a "fair ecological condition" as in Smakhtin et al. (2004). Including social and political decisions in quantitative assessment is very difficult and beyond the aim of this paper. At the moment, we cannot possibly address this new research agenda, and we have limited ourselves to the quantification of EFRs as a function of biophysical parameters. However, we acknowledge that there is a need for a more systematic EF method that would link the natural and social science fronts and create a unifying framework for the assessment and implementation of sustainable EFRs in national water policies (Pahl-Wostl et al., 2013). Additional efforts are required to develop a systematic regional environmental flow framework based on multi-disciplinary methods (Poff et al., 2009; Pahl-Wostl et al., 2013). Addressing EFRs, which is part of a proactive management of river basins, is certainly a less costly solution than using reactive solutions such as river restoration measures (Palmer et al., 2008).

\subsection{Refining global water assessments}

This study aimed not to refine locally determined EF methods but to identify one or several methods for global application. These new estimates of EFRs will improve global water availability assessments and allow them to better inform other water users. Moreover, expansion of irrigated lands can be carried out in a more sustainable way by accounting for current and future water availability constrained by EFRs. The VMF method estimated that at least $40 \%$ of global annual flow should be reserved for environmental flows to keep ecosystems in a fair ecological condition, but that does not necessarily mean that the remaining $60 \%$ of the water should be used by other users. It is important to acknowledge that this is a global annual average and that EFRs are highly variable depending on the region and the flow season. Finally, there is no EFR benchmark at a river basin scale. That is why we show in Fig. 7 a range of annual EFRs at a river basin scale by using a range of the five hydrological EF methods. This approach can guide policy-makers who have to decide for EFRs values in different river basins where ecological and hydrological data are poor and it could be a starting point to implement EFRs at river basin level with "fair" ecological conditions. In future global EF assessments, it will be important to consider the inter-annual variability of flow regimes because EFRs are usually calculated on a long period average ( $>20$ years) and they might need to be refined for dry years (Hessari et al., 2012). Regarding the use of ecolog- ical data sets, it is worth considering the delay in ecosystem response related to flow events when calculating EFRs (Sun et al., 2008).

\section{Conclusions}

We tested five different hydrological environmental flow methods for their applicability in global water assessments and found the VMF and Tessmann methods to be valid and easy methods for implementation in global hydrological models. Both methods use a simple algorithm and also take into account intra-annual variability. They improve environmental flow calculations due to their increased time resolution from an annual to monthly basis and the global applicability that this provides. The VMF and Tessmann methods were validated with existing EFR calculations from local case studies and showed good correlations with locally calculated EFRs. Quantile methods such as Smakhtin, $Q_{90} Q_{50}$, and Tennant showed some disadvantages in variable flow regimes such as a lower allocation of flow than with locally calculated EFRs and flooding of the river during the dry season. The VMF and Tessmann methods fit many different flow regimes thanks to their algorithm determining low, intermediate, and high-flows; its use in future global water assessment is recommended, especially in the case of variable flow regimes. This validation increases our confidence in using this method in global water assessments. However, EFRs are likely to be adjusted if society wishes to implement a different ecological status for the river. For example, a higher flow allocation might be desired if excellent ecological conditions are required. For that eventuality, we create algorithms that are easily adjusted to societal needs. In the absence of any local calculation of EFRs, using the five hydrological methods can also provide a range of calculated EFRs at global and river basin scale in "fair" ecological conditions. Including EFRs in future global water assessments will improve the estimates of global water boundaries and will enable sustainable scenarios to be produced on the expansion of irrigated land and on the use of water for other users such as the hydropower sector.

Acknowledgements. We thank the following individuals who contributed to this study for their comments and for sharing data resources: Knut Alfredsen, David S. Armstrong, Jorge Alcazar, Patrick B. Shafroth, Naota Hanasaki, and Dolores Bejarano. We also thank Kathryn Platzer for proofreading the manuscript. Funding for this study has been provided by the NWO (Netherlands Organization for Scientific Research) within the program: "Planetaire grenzen zoetwatercyclus".

Edited by: S. Archfield 


\section{References}

Abell, R., Thieme, M. L., Revenga, C., Bryer, M., Kottelat, M., Bogutskaya, N., Coad, B., Mandrak, N., Balderas, S. C., and Bussing, W.: Freshwater ecoregions of the world: A new map of biogeographic units for freshwater biodiversity conservation, Bioscience, 58, 403-414, 2008.

Acreman, M., Dunbar, M., Hannaford, J., Mountford, O., Wood, P., Holmes, N., Cowx, I., Noble, R., Extence, C., and Aldrick, J.: Developing environmental standards for abstractions from uk rivers to implement the eu water framework directive/développement de standards environnementaux sur les prélèvements d'eau en rivière au royaume uni pour la mise en œuvre de la directive cadre sur l'eau de l'union européenne, Hydrol. Sci. J., 53, 1105-1120, 2008.

Alcamo, J., Flörke, M., and Märker, M.: Future long-term changes in global water resources driven by socio-economic and climatic changes, Hydrol. Sci. J., 52, 247-275, 2007.

Alexandratos, N. and Bruinsma, J.: World agriculture towards 2030/2050: The 2012 revision, ESA Working paper, 2012.

Allain, M. and El-Jabi, N.: Hydrological approach to instream flow evaluation: A sensitivity analysis, Annual Conference of the Canadian Society for Civil Engineering, Montréal, Québec, Canada, 2002.

Armstrong, D. S., Todd, A., and Parker, G. W.: Assessment of habitat, fish communities, and streamflow requirements for habitat protection, ipswich river, Massachusetts, 1998-99, Issue 1, Dept. of the Interior, US Geological Survey, 20011999.

Arnell, N. W.: Climate change and global water resources: Sres emissions and socio-economic scenarios, Global Environ. Change, 14, 31-52, doi:10.1016/j.gloenvcha.2003.10.006, 2004.

Arthington, A. H., Rall, J. L., Kennard, M. J., and Pusey, B. J.: Environmental flow requirements of fish in lesotho rivers using the drift methodology, River Res. Applic., 19, 641-666, 2003.

Arthington, A. H., Bunn, S. E., Poff, N. L., and Naiman, R. J.: The challenge of providing environmental flow rules to sustain river ecosystems, Ecol. Appl., 16, 1311-1318, doi:10.1890/10510761(2006)016[1311:TCOPEF]2.0.CO;2., 2006.

Babel, M. S., Dinh, C. N., Mullick, M. R. A., and Nanduri, U. V.: Operation of a hydropower system considering environmental flow requirements: A case study in la nga river basin, vietnam, J. Hydro-Environ. Res., 6, 63-73, doi:10.1016/j.jher.2011.05.006, 2012.

Barnosky, A. D., Hadly, E. A., Bascompte, J., Berlow, E. L., Brown, J. H., Fortelius, M., Getz, W. M., Harte, J., Hastings, A., and Marquet, P. A.: Approaching a state shift in earth/'s biosphere, Nature, 486, 52-58, 2012.

Bejarano, D. M., Nilsson, C., Del tanago, G. M., and Marchamalo, M.: Responses of riparian trees and shrubs to flow regulation along a boreal stream in northern sweden, Freshw. Biol., 56, 853866, 2011.

Biemans, H., Haddeland, I., Kabat, P., Ludwig, F., Hutjes, R., Heinke, J., von Bloh, W., and Gerten, D.: Impact of reservoirs on river discharge and irrigation water supply during the 20th century, Water Resour. Res., 47, W03509, doi:10.1029/2009WR008929, 2011.

Bigas, H. E.: The global water crisis: Addressing an urgent security issue, UNU-INWEH, Hamilton, Canada, 2012.
Bond, N. R., Lake, P., and Arthington, A. H.: The impacts of drought on freshwater ecosystems: An australian perspective, Hydrobiologia, 600, 3-16, 2008.

Bondeau, A., Smith, P. C., Zaehle, S., Schaphoff, S., Lucht, W., Cramer, W., Gerten, D., Lotze Campen, H., Müller, C., and Reichstein, M.: Modelling the role of agriculture for the 20th century global terrestrial carbon balance, Global Change Biol., 13, 679-706, 2007.

Botter, G., Basso, S., Rodriguez-Iturbe, I., and Rinaldo, A.: Resilience of river flow regimes, Proc. Natl. Acad. Sci., 110, 1292512930, 2013.

Bovee, K. D.: Development and evaluation of habitat suitability criteria for use in the instream flow incremental methodology, National Ecology Center, Division of Wildlife and Contaminant Research, Fish and Wildlife Service, US Department of the Interior, 1986.

Bovee, K. D., Lamb, B. L., Bartholow, J. M., Stalnaker, C. B., and Taylor, J.: Stream habitat analysis using the instream flow incremental methodology, US Geological Survey-BDR, Fort Collins, CO, USA, p. 130, 1998.

Bunn, S. E. and Arthington, A. H.: Basic principles and ecological consequences of altered flow regimes for aquatic biodiversity, Environ. Manage., 30, 492-507, doi:10.1007/s00267-002-2737$0,2002$.

Capra, H., Sabaton, C., Gouraud, V., Souchon, Y., and Lim, P.: A population dynamics model and habitat simulation as a tool to predict brown trout demography in natural and bypassed stream reaches, River Res. Appl., 19, 551-568, doi:10.1002/Rra.729, 2003.

Changming, L. and Shifeng, Z.: Drying up of the yellow river: Its impacts and counter-measures, Mitigation and Adaptation Strategies for Global Change, 7, 203-214, doi:10.1023/a:1024408310869, 2002.

Council, E. P.: Directive of the european parliament and of the council 2000/60/ec establishing a framework for community action in the field of water policy, European Commission PE-CONS, 3639, 100, 2000.

Declaration, T. B.: The brisbane declaration: Environmental flows are essential for freshwater ecosystem health and human wellbeing, Declaration of the 10th International River Symposium, 3-6 September 2007, Brisbane, Australia, 2007.

Döll, P., Kaspar, F., and Lehner, B.: A global hydrological model for deriving water availability indicators: Model tuning and validation, J. Hydrol., 270, 105-134, doi:10.1016/S00221694(02)00283-4, 2003.

Doupé, R. and Pettit, N.: Ecological perspectives on regulation and water allocation for the ord river, western australia, River Res. Appl., 18, 307-320, 2002.

Dudgeon, D.: Large-scale hydrological changes in tropical asia: Prospects for riverine biodiversity, Bioscience, 50, 793-806, 2000.

DWAF: White paper on a national water policy for south africa, Department of Water Affairs and Forestry, Pretoria, South Africa, 1997.

Espegren, G. D.: Evaluation of the standards and methods used for quantifying instream flows in colorado, Colorado Water Conservation Board, Denver, CO, USA, 1998. 
Estes, C. C.: Annual summary of instream flow reservations and protection in alaska, Alaska Department of Fish and Game, Division of Sport Fish, Research and Technical Services, 1998.

Fader, M., Rost, S., Müller, C., Bondeau, A., and Gerten, D.: Virtual water content of temperate cereals and maize: Present and potential future patterns, J. Hydrol., 384, 218-231, 2010.

Gerten, D., Schaphoff, S., Haberlandt, U., Lucht, W., and Sitch, S.: Terrestrial vegetation and water balance - hydrological evaluation of a dynamic global vegetation model, J. Hydrol., 286, 249270, 2004

Gerten, D., Hoff, H., Rockström, J., Jägermeyr, J., Kummu, M., and Pastor, A. V.: Towards a revised planetary boundary for consumptive freshwater use: role of environmental flow requirements, Current Opinion in Environmental Sustainability, 5, 551558, doi:10.1016/j.cosust.2013.11.001, 2013.

Gippel, C. J. and Stewardson, M. J.: Use of wetted perimeter in defining minimum environmental flows, Regulated rivers: Res. Manage., 14, 53-67, 1998.

Gleeson, T., Wada, Y., Bierkens, M. F., and van Beek, L. P.: Water balance of global aquifers revealed by groundwater footprint, Nature, 488, 197-200, 2012.

Gleick, P. H.: Global freshwater resources: Soft-path solutions for the 21st century, Science, 302, 1524-1528, 2003.

Haines, A., Finlayson, B., and McMahon, T.: A global classification of river regimes, Appl. Geogr., 8, 255-272, 1988.

Hanasaki, N., Kanae, S., Oki, T., Masuda, K., Motoya, K., Shirakawa, N., Shen, Y., and Tanaka, K.: An integrated model for the assessment of global water resources - Part 1: Model description and input meteorological forcing, Hydrol. Earth Syst. Sci., 12, 1007-1025, doi:10.5194/hess-12-1007-2008, 2008.

Hessari, B., Bruggeman, A., Akhoond-Ali, A., Oweis, T., and Abbasi, F.: Supplemental irrigation potential and impact on downstream flow of Karkheh River Basin of Iran, Hydrol. Earth Syst. Sci. Discuss., 9, 13519-13536, doi:10.5194/hessd9-13519-2012, 2012.

Hoekstra, A. Y. and Mekonnen, M. M.: Global water scarcity: The monthly blue water footprint compared to blue water availability for the world's major river basins, UNESCO-IHE Institute for Water Education, Delft, The Netherlands, No. 53, 78 pp., 2011.

Hoekstra, A. Y. and Mekonnen, M. M.: The water footprint of humanity, Proc. Natl. Acad. Sci., 109, 3232-3237, doi:10.1073/pnas.1109936109, 2012.

Hoekstra, A. Y., Mekonnen, M. M., Chapagain, A. K., Mathews, R. E., and Richter, B. D.: Global monthly water scarcity: Blue water footprints versus blue water availability, PLoS One, 7, 2:e32688, 2012.

Hoff, H., Falkenmark, M., Gerten, D., Gordon, L., Karlberg, L., and Rockström, J.: Greening the global water system, J. Hydrol., 384, 177-186, 2010.

Hughes, D. A.: Providing hydrological information and data analysis tools for the determination of ecological instream flow requirements for south african rivers, J. Hydrol., 241, 140-151, doi:10.1016/S0022-1694(00)00378-4, 2001.

Hugues, F. M. R. and Rood, S. B.: Allocation of river flows for restoration of floodplain forest ecosystems: A review of approaches and their applicability in europe, Environ. Manage., 32, 12-33, doi:10.1007/s00267-003-2834-8, 2003.

Iwasaki, Y., Ryo, M., Sui, P., and Yoshimura, C.: Evaluating the relationship between basin-scale fish species richness and ecolog- ically relevant flow characteristics in rivers worldwide, Freshw. Biol., 57, 2173-2180, 2012.

Yoshikawa, S., Yanagawa, A., Iwasaki, Y., Sui, P., Koirala, S., Hirano, K., Khajuria, A., Mahendran, R., Hirabayashi, Y., Yoshimura, C., and Kanae, S.: Illustrating a new global-scale approach to estimating potential reduction in fish species richness due to flow alteration, Hydrol. Earth Syst. Sci., 18, 621-630, doi:10.5194/hess-18-621-2014, 2014.

Jowett, I.: River hydraulic and habitat simulation, rhyhabsim computer manual, Ministry of Agriculture and Fisheries, Christchurch, New Zealand, Report 49, 39 pp., 1989.

Kashaigili, J. J., McCartney, M., and Mahoo, H. F.: Estimation of environmental flows in the great ruaha river catchment, tanzania, Phys. Chem. Earth, Parts A/B/C, 32, 1007-1014, doi:10.1016/j.pce.2007.07.005, 2007.

Kennard, M. J., Mackay, S. J., Pusey, B. J., Olden, J. D., and Marsh, N.: Quantifying uncertainty in estimation of hydrologic metrics for ecohydrological studies, River Res. Appl., 26, 137-156, 2010.

King, J. and Louw, D.: Instream flow assessments for regulated rivers in south africa using the building block methodology, Aqua. Ecosyst. Health Manage., 1, 109-124, doi:10.1080/14634989808656909, 1998.

King, J. and Brown, C.: Integrated basin flow assessments: Concepts and method development in africa and southeast asia, Freshw. Biol., 55, 127-146, doi:10.1111/j.13652427.2009.02316.x, 2010.

Kingsford, R. T. and Auld, K. M.: Waterbird breeding and environmental flow management in the macquarie marshes, arid australia, River Res. Appl., 21, 187-200, doi:10.1002/Rra.840, 2005.

Liang, X., Lettenmaier, D. P., Wood, E. F., and Burges, S. J.: A simple hydrologically based model of land surface water and energy fluxes for general circulation models, J. Geophys. Res.-Atmos. (1984-2012), 99, 14415-14428, 1994.

Loh, J., Collen, B., McRae, L., Deinet, S., De Palma, A., Manley, R., and Baillie, J. E. M.: Living planet report 2010, WWF International, Gland, Switzerland, 2010.

Marchetti, M. P. and Moyle, P. B.: Effects of flow regime on fish assemblages in a regulated california stream, Ecol. Appl., 11, 530-539, doi:10.1890/10510761(2001)011[0530:EOFROF]2.0.CO;2, 2001.

Mathews, R. and Richter, B. D.: Application of the indicators of hydrologic alteration software in environmental flow setting, JAWRA J. Am. Water Resour. Assoc., 43, 1400-1413, doi:10.1111/j.1752-1688.2007.00099.x, 2007.

McMahon, T. A., Peel, M. C., Vogel, R. M., and Pegram, G. G. S.: Global streamflows - part 3: Country and climate zone characteristics, J. Hydrol., 347, 272-291, 2007.

McManamay, R. A., Orth, D. J., Dolloff, C. A., and Mathews, D. C.: Application of the eloha framework to regulated rivers in the upper tennessee river basin: A case study, Environ. Manage., 51, 1-26, 2013.

Milhous, R. T.: History, theory, use, and limitations of the physical habitat simulation system, Proceedings of the Third International Symposium on Ecohydraulics, Utah State University Extension. Logan, Utah, 1999, 
Nash, J. E. and Sutcliffe, J. V.: River flow forecasting through conceptual models part $\mathrm{i}-$ a discussion of principles, J. Hydrol., 10, 282-290, doi:10.1016/0022-1694(70)90255-6, 1970.

NGPRP: Instream needs sub-group report, Environmental Quality Council, Helena, Mont., USA, 244 pp., 1974.

O'Keeffe, J.: Sustaining river ecosystems: Balancing use and protection, Progr. Phys. Geogr., 33, 339-357, doi:10.1177/0309133309342645, 2009.

O'Keeffe, J. and Quesne, T.: Keeping rivers alive: A primer on environmental flows, Wwf water security series 2, 39 pp., 2009.

Oberdorff, T., Tedesco, P. A., Hugueny, B., Leprieur, F., Beauchard, O., Brosse, S., and Dürr, H. H.: Global and regional patterns in riverine fish species richness: A review, Int. J. Ecol., 967631, 12 pp., doi:10.1155/2011/967631, 2011.

Pahl-Wostl, C., Arthington, A., Bogardi, J., Bunn, S. E., Hoff, H., Lebel, L., Nikitina, E., Palmer, M., Poff, L. N., Richards, K., Schlüter, M., Schulze, R., St-Hilaire, A., Tharme, R., Tockner, K., and Tsegai, D.: Environmental flows and water governance: Managing sustainable water uses, Current Opinion Environ. Sustain., 5, 341-351, doi:10.1016/j.cosust.2013.06.009, 2013.

Palau, A.: Integrated environmental management of current reservoirs and regulated rivers, Limnetica, 25, 287-302, 2006.

Palau, A. and Alcázar, J.: The basic flow method for incorporating flow variability in environmental flows, River Res. Appli., 28, 93-102, 2010.

Palmer, M. A., Reidy Liermann, C. A., Nilsson, C., Flörke, M., Alcamo, J., Lake, P. S., and Bond, N.: Climate change and the world's river basins: Anticipating management options, Front. Ecol. Environ., 6, 81-89, 2008.

Pettit, N. E., Froend, R. H., and Davies, P. M.: Identifying the natural flow regime and the relationship with riparian vegetation for two contrasting western australian rivers, Regul. Rivers-Res. Manage., 17, 201-215, doi:10.1002/Rrr.624, 2001.

Poff, N. L., Richter, B. D., Arthington, A. H., Bunn, S. E., Naiman, R. J., Kendy, E., Acreman, M., Apse, C., Bledsoe, B. P., and Freeman, M. C.: The ecological limits of hydrologic alteration (eloha): A new framework for developing regional environmental flow standards, Freshw. Biol., 55, 147-170, 2009.

Poff, N. L. and Zimmerman, J. K.: Ecological responses to altered flow regimes: A literature review to inform the science and management of environmental flows, Freshw. Biol., 55, 194-205, 2010.

Pokhrel, Y., Hanasaki, N., Koirala, S., Cho, J., Yeh, P. J. F., Kim, H., Kanae, S., and Oki, T.: Incorporating anthropogenic water regulation modules into a land surface model, J. Hydrometeorol., 13, 255-269, doi:10.1175/jhm-d-11-013.1, 2011.

Portmann, F. T., Siebert, S., and Döll, P.: Mirca2000 - global monthly irrigated and rainfed crop areas around the year 2000: A new high-resolution data set for agricultural and hydrological modeling, Global Biogeochem. Cy., 24, GB1011, doi:10.1029/2008gb003435, 2010.

Pouilly, M. and Aguilera, G.: Evaluación inicial de caudales ecológicos/ambientales en la cuenca del río huasco - chile, mediante la simulación del hábitat físico del pejerrey basilichthys microlepidotus y el camarón de río cryphiops caementarius, UICN, Quito, Ecuador., 57, 2012.

Richter, B. D., Baumgartner, J., Wigington, R., and Braun, D.: How much water does a river need?, Freshw. Biol., 37, 231-249, doi:10.1046/j.1365-2427.1997.00153.x, 1997.
Richter, B. D., Mathews, R., Harrison, D. L., and Wigington, R.: Ecologically sustainable water management: Managing river flows for ecological integrity, Ecol. Appl., 13, 206-224, doi:10.1890/1051-0761(2003)013[0206:ESWMMR]2.0.CO;2, 2003.

Richter, B. D., Warner, A. T., Meyer, J. L., and Lutz, K.: A collaborative and adaptive process for developing environmental flow recommendations, River Res. Appl., 22, 297-318, 2006.

Richter, B. D.: Re-thinking environmental flows: From allocations and reserves to sustainability boundaries, River Res. Appl., 26, 1052-1063, 2010.

Richter, B. D., Davis, M. M., Apse, C., and Konrad, C.: A presumptive standard for environmental flow protection, River Res. Appl., 28, 1312-1321, 2012.

Rockström, J., Falkenmark, M., Karlberg, L., Hoff, H., Rost, S., and Gerten, D.: Future water availability for global food production: The potential of green water for increasing resilience to global change, Water Resour. Res., 45, W00A12, doi:10.1029/2007wr006767, 2009.

Rost, S., Gerten, D., Bondeau, A., Lucht, W., Rohwer, J., and Schaphoff, S.: Agricultural green and blue water consumption and its influence on the global water system, Water Resources Research, 44, W09405, doi:10.1029/2007wr006331, 2008.

Shafroth, P. B., Wilcox, A. C., Lytle, D. A., Hickey, J. T., Andersen, D. C., Beauchamp, V. B., Hautzinger, A., Mcmullen, L. E., and Warner, A.: Ecosystem effects of environmental flows: Modelling and experimental floods in a dryland river, Freshw. Biol., 55, 68-85, 2009.

Sitch, S., Smith, B., Prentice, I. C., Arneth, A., Bondeau, A., Cramer, W., Kaplan, J., Levis, S., Lucht, W., and Sykes, M. T.: Evaluation of ecosystem dynamics, plant geography and terrestrial carbon cycling in the LPJ dynamic global vegetation model, Global Change Biol., 9, 161-185, doi:10.1046/j.13652486.2003.00569.x, 2003.

Smakhtin, V., Revenga, C., and Doll, P.: A pilot global assessment of environmental water requirements and scarcity, Water Int., 29, 307-317, 2004.

Smakhtin, V. U., Shilpakar, R. L., and Hughes, D. A.: Hydrologybased assessment of environmental flows: An example from nepal, Hydrol. Sci. J., 51, 207-222, doi:10.1623/hysj.51.2.207, 2006.

Sun, T., Yang, Z., and Cui, B.: Critical environmental flows to support integrated ecological objectives for the yellow river estuary, china, Water Resour. Manage., 22, 973-989, 2008.

Symphorian, G. R., Madamombe, E., and van der Zaag, P.: Dam operation for environmental water releases; the case of osborne dam, save catchment, zimbabwe, Phys. Chem. Earth, Parts A/B/C, 28, 985-993, 2003.

Telis, P. A. and District, P. H. W.: Techniques for estimating 7-day, 10-year low-flow characteristics for ungaged sites on streams in mississippi, US Geological Survey, Tallahassee, MS, USA, Water-Resources Invertigations Report 91-4130, 143 pp., 1992.

Tennant, D. L.: Instream flow regimens for fish, wildlife, recreation and related environmental resources, Fisheries, 1, 6-10, 1976.

Tessmann, S.: Environmental assessment, technical appendix e in environmental use sector reconnaissance elements of the western dakotas region of south dakota study. South dakota state university, Water Resources Institute, South Dakota State University, Brookings, South Dakota, 1980. 
Tharme, R. E.: A global perspective on environmental flow assessment: Emerging trends in the development and application of environmental flow methodologies for rivers, River Res. Appl., 19, 397-441, doi:10.1002/Rra.736, 2003.

van Beek, L. P. H., Wada, Y., and Bierkens, M. F. P.: Global monthly water stress: 1. Water balance and water availability, Water Resour. Res., 47, W07517, doi:10.1029/2010wr009791, 2011.

Vliet, M. H., Ludwig, F., and Kabat, P.: Global streamflow and thermal habitats of freshwater fishes under climate change, Climatic Change, 121, 739-754, doi:10.1007/s10584-013-0976-0, 2013.

Vorosmarty, C. J., McIntyre, P. B., Gessner, M. O., Dudgeon, D., Prusevich, A., Green, P., Glidden, S., Bunn, S. E., Sullivan, C. A., Liermann, C. R., and Davies, P. M.: Global threats to human water security and river biodiversity Nature, 468, 334-334, doi:10.1038/Nature09549, 2010.
Werth, S. and Güntner, A.: Calibration analysis for water storage variability of the global hydrological model wghm, Hydrol. Earth Syst. Sci., 14, 59-78, doi:10.5194/hess-14-59-2010, 2010.

Xenopoulos, M. A., Lodge, D. M., Alcamo, J., Märker, M., Schulze, K., and Van Vuuren, D. P.: Scenarios of freshwater fish extinctions from climate change and water withdrawal, Glob. Change Biol., 11, 1557-1564, doi:10.1111/j.1365-2486.2005.001008.x, 2005.

Yasi, M., Karimi, S. S., and Yasi, A.: Eco-hydrological approach for determining environmental flows in rivers 9th International Symposium on Ecohydraulics 2012, Vienna, Austria, 17-21 September 2012 .

Ziv, G., Baran, E., Nam, S., Rodríguez-Iturbe, I., and Levin, S. A.: Trading-off fish biodiversity, food security, and hydropower in the mekong river basin, Proc. Natl. Acad. Sci., 109, 5609-5614, 2012 . 